Gerando possibilidades de uso da proposta curricular do estado para alunos com necessidades especiais

Renata Oliveira Alves Diniz 
Data de Depósito:

Assinatura:

\title{
Gerando possibilidades de uso da proposta curricular do estado para alunos com necessidades especiais
}

\author{
Renata Oliveira Alves Diniz
}

Orientadora: Profa. Dra. Edna Maura Zuffi

Dissertação apresentada ao Instituto de Ciências Matemáticas e de Computação - ICMC-USP, como parte dos requisitos para obtenção do título de Mestre em Ciências - Programa de Mestrado Profissional em Matemática. VERSÃO REVISADA 
Ficha catalográfica elaborada pela Biblioteca Prof. Achille Bassi

e Seção Técnica de Informática, ICMC/USP, com os dados fornecidos pelo(a) autor(a)

D585g

Diniz, Renata Oliveira Alves

Gerando possibilidades de uso da proposta curricular do estado para alunos com necessidades especiais / Renata Oliveira Alves Diniz; orientadora Edna Maura Zuffi. -São Carlos, 2013.

$69 \mathrm{p}$.

Dissertação (Mestrado - Programa de Pós-Graduação em Mestrado Profissional em Matemática em Rede Nacional (PROFMAT)) -- Instituto de Ciências Matemáticas e de Computação, Universidade de São Paulo, 2013.

1. Currículo. 2. Matemática. 3. Necessidades Educacionais Especiais. I. Zuffi, Edna Maura, orient. II. Título. 
"A mente que se abre a uma nova ideia jamais voltará ao seu tamanho original".

(Albert Einstein) 


\section{Dedicatória e Agradecimento}

Dedico este trabalho e agradeço a minha mãe, Irene, meu marido, Alexandre, e meus filhos Aline e Fábio, pela presença, apoio e carinho que a mim dispensaram. Desculpem por toda a minha ausência.

Agradeço também a Deus, aos meus amigos de trabalho e aos novos amigos que fiz durante estes dois anos. Nós sofremos, estudamos e rimos juntos. Não foi fácil, porém foi muito gratificante e, claro, se tivesse que fazer de novo, com vocês eu faria.

À professora Ires e ao professor Hermano que sempre estiveram ao nosso lado e a todos os outros professores que, aos sábados, quando poderiam estar com suas famílias, estiveram conosco.

À professora e orientadora Edna, por sua dedicação, paciência e profissionalismo. Obrigada pela confiança em mim depositada e por ter aceitado a orientação de minha dissertação. Pretendo retribuir com a seriedade de meu trabalho.

E, finalmente, faço minhas as palavras de Francisco Cândido Xavier: "Agradeço por todas as dificuldades que enfrentei; não fosse por elas, eu não teria saído do lugar. As facilidades nos impedem de caminhar. Mesmo as críticas nos auxiliam muito". 


\section{Resumo}

Este trabalho consiste no estudo de propostas de atividades didáticas para alunos com necessidades educacionais especiais, particularmente daquelas que são recomendadas para as salas de aula das escolas públicas estaduais de São Paulo. Teve por objetivos, construir ou adaptar, conforme o caso, aplicar e analisar uma sequência didática, para promover uma aprendizagem adequada a dois alunos com necessidades educacionais especiais, inseridos em uma sala de aula comum, sendo ambos classificados como portadores de paralisia cerebral. Caracterizaremos algumas deficiências que aparecem em escolas comuns ou regulares. Baseando-nos na Proposta Curricular do Estado de São Paulo e também nas Diretrizes Curriculares da Prefeitura de Campinas, como produto deste trabalho, propusemos dois planos de ensino a serem aplicados no sexto e oitavo anos do ensino fundamental e estudamos quais deveriam ser as adaptações desses planos, para adequá-los a esses alunos, sendo um do oitavo e outro do sexto ano do ensino fundamental. Ambas as sequências didáticas foram aplicadas e analisadas, donde concluímos que foram adequadas à aprendizagem de todos os alunos presentes em classe. Porém, também constatamos que as deficiências que aparecem nas escolas, mesmo tendo a mesma classificação, não podem ser tratadas com igualdade, no sentido de que os planos de ensino devem ser adaptados para as necessidades específicas de cada aluno.

Palavras-chaves: Currículo, matemática, necessidade educacional especial. 


\section{Abstract}

This research studies proposals of didactic activities to students with special educational needs, particularly those recommended to public schools in the State of São Paulo, Brazil. We characterize some technical deficiencies which arise in regular schools, and specifically some of our case study. Our main aim was to propose, apply, and analyze a didactical sequence, in order to promote significant learning to students with special needs, inserted in regular classroom, both classified as cerebral palsy. Based on the Curricular Proposals of the State of São Paulo, and also in the curricular directions of the city of Campinas, as a production of this study, we have proposed two teaching plans to be applied to the sixth and eighth grades of basic school. We have studied which adaptations should be done in such plans to fit them to those students. We have applied both the didactical sequences, and concluded that they were appropriate to the learning of all students present in class. However, we also have seen that deficiencies that appear in regular schools, even when they have same classification, should not be treated as equals, in the sense that the educational plans need to be adapted to each student's specific needs.

Keywords: curriculum, mathematics, special educational needs. 
Sumário

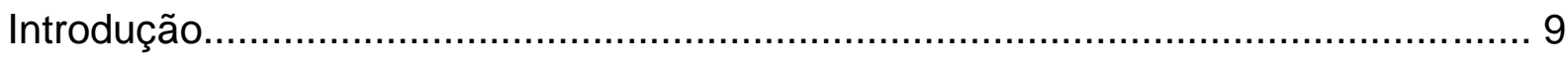

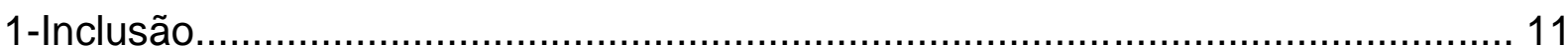

1.1 A questão "igualdade e diferença"na escola............................................ 11

1.2 Atendimento escolar de alunos com necessidades educacionais especiais: um olhar sobre as políticas públicas.................................................. 12

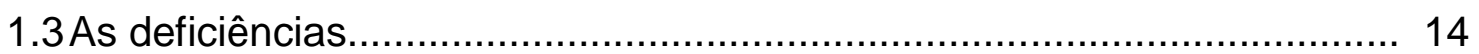

2- Metodologia da Pesquisa e Caracterização dos Sujeitos Investigados................. 19

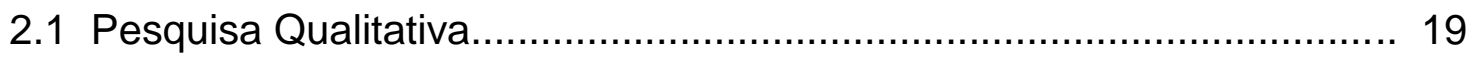

2.1.1 Estudo de caso................................................................ 19

2.1.3 Pesquisa-ação................................................................. 20

2.2 As Metodologias Qualitativas e o Objeto de Estudo............................. 21

2.3 Caracterização da Escola.................................................................. 22

2.4 Caracterização dos dois alunos investigados ................................... 23

3- A construção dos Planos de Ensino........................................................... 25

3.1-Habilidades e Conteúdos para o 6ํe e ํㅡㄹ Anos do Ensino Fundamental. .25

3.1.1 Proposta Curricular do Estado de São Paulo............................. 25

3.1.2 Diretrizes Curriculares de Matemática da Prefeitura de

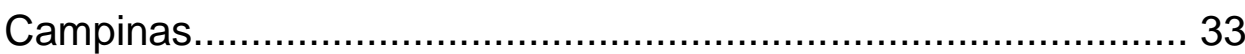

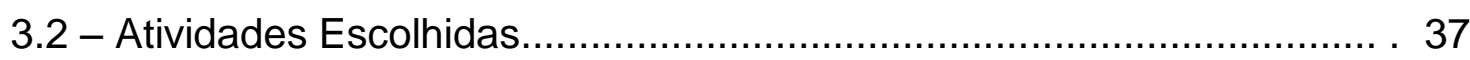

3.2.1 O plano de ensino construído para o 6을 a A ............................. 37

3.2.2 O plano de ensino construído para o 8 ano A............................. 43

4- Análise da Aplicação das Atividades.............................................................. 48

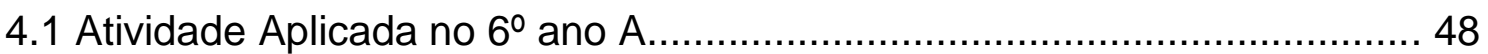

4.2 Atividade Aplicada no 8 ano A......................................................... 58

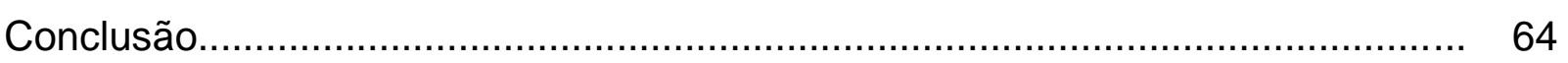

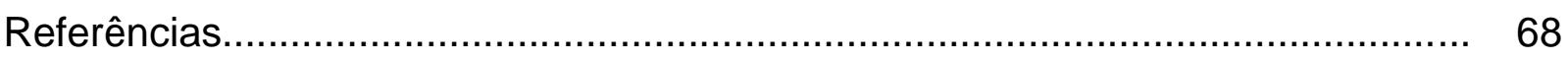




\section{Introducão}

Pela grande preocupação com o desenvolvimento na área tecnológica, verificamos que precisa ser melhorado o desempenho dos alunos em Matemática. Os estudantes precisam ser bem preparados em sua formação inicial, para dar continuidade a seus estudos ou incluir-se no mundo do trabalho. Pensando assim, é necessário nos preocupar mais com uma educação de qualidade para os alunos com necessidades educacionais especiais, inseridos nas escolas públicas.

Esta preocupação com os alunos da educação especial vem surgindo ao longo de nossa trajetória profissional, pois foram aparecendo, em salas de aula comuns (regulares), cada vez mais, alunos com necessidades educacionais especiais. Como inserir este aluno no mercado de trabalho? Esta função também é da escola, ou só da instituição especial que os acompanham?

Pensando que estes estão na escola e nós, professores, devemos orientar e fazer planos de ensino que também os envolvam em seu próprio aprendizado, precisamos aprender sobre a legislação vigente, além de obtermos informações mais precisas sobre as deficiências, para que possamos orientá-los adequadamente, assim como o fazemos com os demais alunos.

Se existe uma deficiência, existe uma diferença, e acreditando nisto, a escola comum tem que se preparar para atendê-los. Devemos então, nos atentar para fatores do ambiente cultural da escola e da comunidade em que estes estão inseridos, fazendo com que se envolvam no processo de ensino aprendizagem.

Portanto, precisamos de mudanças efetivas na formação de professores, bem como adequar o material pedagógico utilizado e os recursos já existentes, para atender a essas diferenças. Também é preciso direcionar o currículo escolar a este alunado, e não simplesmente oferecer-lhes qualquer atividade que preencha seu tempo, sem avanços em seu real desenvolvimento. Temos então, que estudar e refletir sobre essas temáticas.

A fim de sustentar a contextualização do atual ambiente das escolas públicas, que são, em geral, as que recebem a maior parte desse alunado, foram estudadas as referências da Proposta Curricular do Estado (São Paulo, 2012), o Caderno do Aluno (São Paulo, 2009) e também a Proposta Curricular da Prefeitura de Campinas (Campinas, 2010). Elas serão a base de nossas análises, pois, além das orientações curriculares gerais para o ensino de Matemática, trazem atividades ricas do ponto de 
vista pedagógico e que podem subsidiar a confecção de um material adaptado às necessidades específicas para a aprendizagem de estudantes especiais.

Atentos a esta declaração, fomos levados a refletir sobre as seguintes questões: $O$ aluno da educação especial, seja qual for a sua deficiência, acompanha as atividades dadas em sala de aula de uma escola pública comum (ou regular)? As atividades propostas no Caderno do Aluno são suficientes para atingir a aprendizagem desejada, incluindo esse alunado diferente? Em todos os casos de inclusão de alunos com deficiência, as aprendizagens desejadas e alcançadas serão as mesmas?

A Declaração de Salamanca (UNESCO, 1994, p.11,12 )diz que:

"O princípio fundamental das escolas inclusivas consiste em que todos os alunos devam aprender juntos, sempre que possível, independentemente das dificuldades e das diferenças que apresentem. As escolas inclusivas devem reconhecer e satisfazer as necessidades diversas dos seus alunos, adaptando aos vários estilos e ritmos de aprendizagem, de modo a garantir um bom nível de educação para todos, através de currículos adequados, de uma boa organização escolar, de estratégias pedagógicas, de utilização de recursos e de uma cooperação com as respectivas comunidades. É preciso, portanto, um conjunto de apoios de serviços para satisfazer o conjunto de necessidades especiais dentro da escola."

A partir desses pressupostos e indagações, no capítulo I, apresentaremos um estudo sobre a questão da inclusão escolar e a legislação brasileira. No capítulo II, caracterizaremos esta pesquisa como um estudo de caso e, portanto, de caráter qualitativo. No capítulo III, apresentaremos as sequências de ensino propostas e no capítulo IV, uma análise de suas aplicações em duas salas de uma escola municipal em Campinas, que incluíam dois alunos classificados como portadores de paralisia cerebral. 


\section{Capítulo I- Inclusão}

Neste capítulo vamos tratar das questões históricas e sociais da inclusão de alunos com necessidades especiais em escolas brasileiras comuns (ou regulares), assim como vamos caracterizar os diversos tipos de deficiências possíveis de serem encontradas nestas escolas.

\subsection{A questão "iqualdade e diferença" na escola}

Uma das maiores preocupações das instituições educacionais é desenvolver um ensino de qualidade para todos e, para que isto ocorra,é preciso encontrar soluções que respondam à questão do acesso e da permanência dos alunos com necessidades educacionais especiais. Para que a escola seja considerada de todos, devemos lidar com a questão da diferença, sem esconder as especificidades e também sem enfatizá-las. Nas escolas todos devem ser tratados com igualdade, "todos são iguais", no que diz respeito ao direito ao acesso ao conhecimento e ao saber, porém devemos também considerar as especificidades de classes heterogêneas e, atualmente, a presença de um alunado "diferente", com dificuldades de ordem física ou mental. Ainda, este todo deve continuar seguindo regras e padrões determinados para a escolarização em séries, anos ou ciclos de aprendizagem.

Enfim, precisamos garantir escolas de qualidade para todos e isto é uma dificuldade, uma vez que o acesso à escola pública ampliou-se, no Brasil, porém sem que os padrões de qualidade atingissem uma grande parte da população escolar. E, tratando-se da inclusão de alunos com necessidades especiais, existem entraves maiores ainda, como a infra estrutura, a preparação dos professores, a resistência das instituições especializadas, as práticas pedagógicas homogeneizadoras e o desconhecimento de muitos pais. Como observa Mantoan e Prieto (2006, p.25), "temos sofrido muita oposição e resistência dos que deveriam estar nos apoiando. Falta vontade de mudar".

Devemos lembrar que fazemos, ainda, educação para uma parcela da sociedade dita "normal", no sentido de não apresentar necessidades específicas para sua inclusão escolar, e esquecemos que uma educação de qualidade para todos deve realmente incluir os alunos com necessidades educacionais especiais. Queremos garantir o acesso, a permanência e o prosseguimento nos estudos e na vida profissional, na medida do possível, também destes alunos, e ter como apoio as 
escolas especiais, que devem complementar, e não substituir, o convívio em uma escola comum(ou regular).

As diferenças, de todos os gêneros em sala de aula trazem um conflito que coloca em questão o que queremos ao final do ano letivo. Ao entrar na escola, os alunos são diferentes e no final do período letivo,pretende-seque estes se igualem em conhecimento, ou seja, que alcancem conhecimentos próximos a um padrão comum estabelecido pelos currículos escolares, e como sabemos que isto não ocorre ao mesmo tempo, esta questão leva à exclusão, à repetência, aos reforços e recuperação escolar. "O certo, porém, é que os alunos jamais deverão ser desvalorizados e inferiorizados pelas suas diferenças" (MANTOAN e PRIETO, 2006).

\subsection{Atendimento escolar de alunos com necessidades educacionais especiais: um olhar sobre as políticas públicas}

Alunos com necessidades educacionais especiais matriculados nas escolas comuns não podem estar aí presentes apenas pela obrigatoriedade legal. A escola deve elaborar planos e projetos pedagógicos específicos para atender a essas diferenças, adaptando a escola ao aluno, dentro de suas possibilidades, e não o contrário. Por outro lado, o aluno também precisa sentir-se comprometido com as atividades escolares. Para isso, esta instituição precisa de modelos que realmente integrem o aluno com necessidades educacionais especiais, respeitando sua individualidade, reconhecendo e valorizando a diversidade para favorecer 0 aprendizado.

Entendemos que uma das peças chaves para que a inclusão aconteça está no papel dos professores, os quais, em geral, ou não tiveram nenhuma, ou tiveram pouca preparação durante a sua vida acadêmica, para lidar com esse alunado especial. Esta falta de capacitação acaba fazendo com que eles não saibam o que fazer quando se deparam com os problemas dos portadores de necessidades especiais, podendo até mesmo deixá-los fora das atividades, e em alguns casos, fazendo com que se sintam mais excluídos ainda.

Também a formação continuada deve ser um compromisso dos sistemas de ensino comprometidos com a qualidade e deve ser oferecida ao professor, para que este consiga adequar as práticas de ensino às características de seus alunos, incluindo aqueles com necessidades educacionais especiais. Os professores devem ser capazes de analisar os conhecimentos prévios e atuais dos alunos, nas suas 
diferentes necessidades, planejar sequências de ensino com atividades e materiais adaptados, além de prever formas de avaliação que forneçam subsídios para sua reflexão e seu replanejamento. Assim, na formação do professor:

"Os conhecimentos sobre o ensino de alunos com necessidades educacionais especiais não podem ser de domínio apenas de alguns especialistas e sim, apropriado pelo maior número de profissionais da educação, idealmente para todos" (Mantoan, Prieto, 2006, p.58)

Em relação ao atendimento às pessoas com necessidades educacionais especiais, se Zuffi, Jacomelli e Palombo (2011), houve muitas transformações durante o século $X X$,baseadas na defesa do direito à integração e na reforma da escola. Primeiramente, elas eram excluídas da sociedade como um todo, inclusive das instituições escolares. Com as mudanças ocorridas na era industrial, do final do século XIX até meados do século XX, houve a necessidade de recolocá-las em seu novo papel social e, partindo do diagnóstico de sua deficiência, estas eram, em geral, encaminhadas para uma instituição de educação especial, pois muitas vezes, seria difícil que se adaptassem ao ensino comum, regular, dito normal.

Com os movimentos sociais que reclamavam os direitos para as pessoas com necessidades educacionais especiais, principalmente a partir da "Declaração de Salamanca", documento gerado durante a Conferência Mundial da Organização das Nações Unidas para a Educação, a Ciência e a Cultura (UNESCO, 1994), uma nova concepção de ensino foi surgindo e com os estudos acadêmicos, um novo olhar para a prática educativa,para além da preocupação com a infra estrutura, propondo mudanças nos currículos, na organização do tempo escolar, na metodologia de ensino empregada, na formação de professores especialistas e consequentemente, um novo olhar no processo de ensino e aprendizagem, visando à educação integral para todos.

Ao inserir esse alunado especial na escola comum (ou regular), ampliou-se a quantidade de alunos nesta condição, porém não se alterou o número de alunos por sala de aula e muitas vezes, com salas superlotadas, os professores, como dito anteriormente, com pouca prática e sem formação suficiente, acabam por excluí-los de muitas de suas atividades.

As necessidades especiais desses estudantes, muitas vezes, não se resumem ao campo da deficiência física ou do desenvolvimento da criança, mas 
também nas condições familiares ou sociais, da organização da escola ou do currículo, isto é, daquilo que o sistema educacional estabelece para alcançar ao final do período letivo. Precisamos observar que a inclusão destes alunos na escola regular também visa inseri-los num espaço em que se aprende a ter atitudes de respeito às diferenças e solidariedade com aqueles que necessitam de apoio às suas dificuldades, sejam elas quais forem.

Por outro lado, as instituições especiais devem ser consideradas um apoio às escolas comuns, pois as primeiras têm maior experiência em adaptações das atividades que poderão ser desenvolvidas nestas últimas. Porém, muitos não acreditam nesta integração, justamente pelo tipo de organização que é atualmente oferecida. Também existe certo receio de pais de filhos com deficiências mais graves em aceitar que estes frequentem a escola regular, pois nem sempre acreditam que seja bem preparada para recebê-los. Por isso, essa integração deverá compor-se de várias organizações e devemos procurar quais serão as mais adequadas para cada necessidade, dentro da situação de aprendizagem em que se inserem ,pois "cada criança tem características, interesses e necessidades de aprendizagens que lhe são próprios" (Coll, Marchesi e Palacios, 2004, p.26).

Se houver uma melhor organização no atendimento aos alunos com necessidades educacionais especiais, com oferecimento de infraestrutura adequada e profissionais mais bem qualificados, efetivamente poderemos cumprir parte da Constituição Federal e da Lei de Diretrizes e Bases da Educação Nacional (LDBEN 9394/96), no que se refere a uma educação para todos, respeitando as igualdades e diferenças.

\subsection{As deficiências}

Embora muitos autores protestem contra o uso do termo "deficiências", para se referir às necessidades especiais de certas pessoas, quanto a suas limitações ou dificuldades psicofisiológicas para um desenvolvimento comum, este termo será aqui usado em seu sentido técnico, ao aglutinar a ideia de ausência de uma capacidade completa para esse desenvolvimento em alguns quesitos, de acordo com os padrões funcionais da grande maioria das pessoas (por exemplo, ao se referirem à deficiência auditiva, visual, física ou mental). Há autores que preferem esse termo técnico mais restritivo, também porque a expressão "pessoa com necessidade especial" é muito ampla e genérica, argumentando que, genericamente, todos têm alguma 
necessidade especial para nosso desenvolvimento, de acordo com anseios e aspirações pessoais, não sendo ela, precisa na caracterização das diferenças psicofisiológicas em questão (Coll, Marchessi e palácios, 2004).

Em salas de aula de ensino comum, a partir da promulgação da mais recente Lei de Diretrizes de Bases da Educação Nacional (LDBEN 9394/96) e segundo Zuffi, Jacomelli e Palombo (2011), podemos encontrar muitos tipos de deficiências:

i) Deficiência auditiva: acomete pessoas privadas de audição, em maior ou menor grau, e que desenvolvem modos alternativos de comunicação. Representam um grupo bastante heterogêneo e, por isso, não é certo fazer generalizações a toda a população que apresenta essa deficiência. $O$ desenvolvimento comunicativo e linguístico dessas pessoas será influenciado pelo ambiente e isso determinará que tipo de linguagem utilizarão. Quando não é possível a aquisição da linguagem oral, em geral, as crianças surdas aprendem a língua dos sinais (no Brasil, chamada LIBRAS) e algumas podem desenvolver habilidades de leitura labial. O desenvolvimento cognitivo desses alunos pode ser equivalente ao dos ouvintes, desde que se estabeleça, de fato, algum tipo de comunicação entre aluno e professor, de modo que ambos se compreendam.

ii) Deficiência visual: é uma classificação para uma população muito heterogênea, desde pessoas que vivem na escuridão total a outras que ainda possuem resquícios de visão. Tais pessoas precisam utilizar os demais sistemas sensoriais para conhecer o mundo à sua volta, sendo o tato e a audição, os principais recursos de que fazem uso, juntamente com outras estratégias. Uma de suas características importantes para o conhecimento de professores e das escolas é que precisam conhecer primeiro as partes dos objetos, através do tato, e somente depois pensar no todo, enquanto que a visão dita "normal" fornece a noção da totalidade de uma só vez. Em geral, para a educação dessas pessoas, é necessário o acesso ao sistema Braille e a escola deve proporcionar todo o material adaptado para promover seu desenvolvimento. É necessário incentivar o conhecimento do espaço físico escolar e possibilitar que se locomovam sem riscos. Atendidas essas condições, é preciso que os professores se conscientizem de que o aluno cego não 
apresenta dificuldades significativas, do ponto de vista da aprendizagem dos conteúdos escolares.

iii) Deficiência mental: caracteriza-se em pessoas que apresentam funcionamento intelectual significativamente abaixo da média $e$ limitações associadas em duas ou mais das seguintes habilidades adaptativas: comunicação, cuidado pessoal, vida doméstica, habilidades sociais, autogoverno, saúde e segurança, habilidades acadêmicas funcionais, lazer e trabalho. Apenas ao longo do desenvolvimento da pessoa e sua resposta à intervenção educativa pode-se discernir a deficiência mental permanente, de outros possíveis atrasos e/ou dificuldades de caráter transitório ou menos generalizado. Os sujeitos com deficiência mental são mais lentos e também menos eficientes em processar informações, há déficit nas destrezas e nos saberes prévios, bem como no uso de estratégias. Mas sempre é possível obter algum desenvolvimento através da educação e, para isso, cabe à escola adaptar o currículo, tirando o foco apenas dos conteúdos escolares e ampliando o desenvolvimento da autonomia e das necessidades básicas do deficiente mental, proporcionando sua inclusão cidadã.

Observamos que no início dos estudos a respeito das deficiências mentais, as pessoas eram diagnosticadas através de testes de QI(coeficiente de inteligência). Até mesmo o diagnóstico dado pelo CID (Código Internacional de Doença) era baseado no teste de inteligência, o qual classificava o retardo mental, simplesmente, em leve, moderado e profundo (Zuffi, Jacomelli e Palombo, 2011). Porém, dificuldades de aprendizagem e atitudes comportamentais mais específicas também podem aparecer no diagnóstico e assim, caracterizá-lo com áreas diferentes.

"O diagnóstico da deficiência mental não se esclarece por supostas categorias e tipos de inteligência. Teorias psicológicas desenvolvimentistas, como as de caráter sociológico e antropológico, têm posições assumidas diante da deficiência mental, mas ainda assim não se conseguiu fechar um conceito (Batista e Mantoan, 2007, p.13).

O aluno com deficiência mental apresenta-se como um dos maiores desafios da educação especial, pois muitas vezes não está inserido nos padrões da escola de 
hoje, pelo fato de não demonstrar sua capacidade cognitiva no nível esperado e ter muita dificuldade de construir conhecimento.

Por outro lado, ao se usar a terminologia de alunos com necessidades educacionais especiais, tende-se a aumentar na escola a quantidade de alunos classificados como deficientes mentais, com um diagnóstico errôneo, pois essa primeira expressão pode se referir apenas a dificuldades de aprendizagem, ou de seguir as regras comportamentais, e então o problema pode estar nas práticas escolares, e não em uma deficiência em si (em seu sentido técnico).

iv) Paralisia cerebral e outras alterações motoras: o termo paralisia cerebral vem sendo empregado atualmente para denominar um conjunto de transtornos muito diversos, que têm em comum o fato de significarem uma alteração, ou alguma perda do controle motor, causada por uma lesão encefálica ocorrida no período pré-natal ou durante a primeira infância. Esta lesão é irreversível; porém, se a atenção, reabilitação física e a educação da criança forem adequadas, é possível obter progressos muito importantes, que podem aproximá-la de um funcionamento normal. Estas alterações e a paralisia se caracterizam pelo não controle dos movimentos voluntários (movimentos descoordenados), como deglutir, falar, segurar um objeto, mover os braços, etc. Se essas pessoas não tiverem atraso mental associado, o que pode ocorrer em vários casos, seu desenvolvimento cognitivo pode ser normal. A escola apenas precisará fornecer alguns apoios que permitam a locomoção, a interação entre profissionais da saúde e os professores, materiais adaptados para que a criança consiga escrever, comer, e manter-se ereta, por exemplo.

v) Autismo e outros Transtornos Globais do Desenvolvimento: o autismo é definido como um isolamento social. A pessoa autista vive mentalmente ausente e não interage com as outras pessoas, não cria laços afetivos, não sente necessidade de comunicação com as demais. Outra característica é a inflexibilidade: os autistas não gostam da mudança, precisam seguir uma rotina nas atividades que só a própria pessoa pode romper e em raras ocasiões. É acompanhado de deficiência mental em $75 \%$ dos casos. 
Ainda segundo Zuffi, Jacomelli e Palombo (2011), outros transtornos globais do desenvolvimento são os de Asperger, de Rett, o transtorno desintegrador da infância e os sem especificação. O primeiro não está associado a uma deficiência mental: para alguns pesquisadores, as pessoas com síndrome de Asperger são autistas com nível intelectual e linguístico elevado. As principais diferenças entre 0 transtorno autista e a síndrome de Asperger é que os portadores desta última não apresentam deficiências estruturais em sua linguagem e, inclusive podem ter capacidades linguísticas muito formais, em alguns casos. A segunda diferença é que eles têm capacidades normais de "inteligência impessoal fria" e frequentemente extraordinária em campos restritos. Já o transtorno de Rett é o extremo oposto da Síndrome de Asperger: vem sempre acompanhado de um profundo ou grave atraso mental. Acredita-se que só aconteça em meninas, por envolver mutação no cromossomo X. As pessoas com Rett têm ausência de atividade funcional com as mãos, isolamento, atraso no desenvolvimento da capacidade de andar, microcefalia, entre outros sintomas. Já o transtorno desintegrador da infância se caracteriza por uma perda de funções e capacidades previamente adquiridas pela criança e ocorre depois dos dois e antes dos dez anos. Existem também pessoas com necessidade de apoio generalizado, as quais possuem mais de uma deficiência e que precisam de materiais e instrumentos especializados para se desenvolver, em várias áreas, como para a comunicação, a mobilidade, os cuidados pessoais e a aprendizagem.

Segundo estudo de Zuffi, Jacomelli e Palombo (2011), a maioria das pesquisas com alunos com deficiências já estudadas em sala de aula de matemática, são referentes às auditivas e visuais, e existem poucas investigações baseadas em alunos classificados como deficientes mentais ou com paralisia cerebral, o que também justifica este estudo. 


\section{Capítulo II - Metodologia da Pesquisa e Caracterização dos Sujeitos Investigados}

Neste capítulo vamos delimitar a metodologia escolhida para esta pesquisa, caracterizando os espaços e os sujeitos da investigação. Ela se caracteriza como um estudo qualitativo, de caráter descritivo e analítico, o qual faz uso de documentos para completar e contextualizar as informações obtidas pelo observador, que interage com a situação estudada,afetando-a e também sendo afetado por ela. Envolve um plano de ação determinado pelo professor-pesquisador, que acompanha, controla e interage no processo, para depois refletir sobre e, em muitos casos, alterar sua prática.

\subsection{Pesquisa Qualitativa}

Segundo André (1995), as características básicas da pesquisa qualitativa são: o ambiente natural como fonte direta de dados; o pesquisador como instrumento da coleta; os dados coletados predominantemente descritivos (porém podemos usar quantidades para descrever dados como aqueles recolhidos através das avaliações diagnósticas, o qual nós professores fazemos durante o início do ano letivo para planejar as aulas no decorrer dos bimestres); a preocupação com o processo é maior que com o produto; a análise dos dados tende a seguir um processo indutivo.

Baseada em suas características gerais, a pesquisa qualitativa pode assumir diversas formas, como o estudo de caso e a pesquisa etnográfica.

\subsubsection{Estudo de caso}

O estudo de caso (André, 1995), que já era utilizado na medicina, psicologia, serviço social, enfermagem, administração e direito, também aparece em estudos educacionais. Como exemplo, podemos citar o estudo de uma escola, de um professor, de um aluno ou sala de aula. O interesse do pesquisador é compreender situações especiais que podem ocorrer no ambiente pesquisado.

De acordo com Ponte (2006), no estudo de um caso, seja ele qual for, é sempre preciso dar atenção à sua história (o modo como se desenvolveu) e ao seu contexto (os elementos exteriores, quer da realidade local, quer de natureza social e sistêmica que mais o influenciaram). 
Para ser considerado um estudo de caso etnográfico, deve preencher os requisitos da etnografia e deve ser bem delimitado, com a escolha, bem justificada, de uma pessoa ou uma sala de aula, por exemplo (André, 1995). A partir de um plano de trabalho flexível, escolhe-se uma unidade a ser estudada e busca-se a formulação de novos conceitos e novas abordagens, a partir do caso investigado. Nesse trabalho, a avaliação e reavaliação devem ser constantes e têm como principal função a tomada de decisão para a reformulação das técnicas de coleta e fundamentos teóricos.

\subsubsection{Pesquisa-ação}

Este tipo de investigação qualitativa baseia-se primeiramente na análise, coleta de dados e conceituação dos problemas a serem pesquisados. Em seguida, demanda um planejamento da ação, sua execução e, em geral, uma nova coleta de dados. E o ciclo de análise deve ser repetido, com a proposta de novas ações, se for o caso (André, 1995).

Um exemplo prático da pesquisa-ação no ambiente escolar é o professor que busca alterar o nível de aprendizagem de sua sala, e para isso, faz uso de nova metodologia. Faz uma análise prévia para diagnosticar, e com um processo de intervenção planejada, vai coletando dados, analisando, relatando e refazendo todo o processo.

Esse tipo de pesquisa pode seguir várias linhas, tendo entre elas um caráter diagnóstico, uma preocupação com o currículo, ou podendo, ainda, ser voltada para o desenvolvimento profissional do professor. Pode ser muito apropriada para discutir a formação continuada de professores e a educação de adultos.

Dentro dessa vertente, desenvolveu-se uma linha denominada "pesquisa participante ou participativa". Nesta, há um envolvimento dos participantes e a necessidade de uma devolutiva sistemática para resultar numa melhoria para um grupo. Existe ainda, a corrente pesquisa-ação institucional, com o objetivo de tornar as relações sociais mais justas numa dada instituição, e a corrente investigação colaborativa, em que predomina o trabalho coletivo e a colaboração intensa entre todos os envolvidos.

Em resumo, todas essas vertentes da pesquisa-ação têm um plano de ação bem delineado, baseado em objetivos que se pretende alcançar e um processo de acompanhamento e controle da ação, além de relatos constantes. 


\subsection{As Metodologias Qualitativas e o Objeto de Estudo}

Esta investigação se enquadra dentro de um estudo de caso e tem características de uma pesquisa-ação, sendo, portanto, de caráter qualitativo (André, 1995).Para caracterizá-la como tal, utilizamos a leitura e interpretação de textos, livros e artigos que contextualizam a educação inclusiva e os métodos de ensino para alunos com necessidades educativas especiais. Especificamente, também serão apresentados, neste trabalho, aspectos dos currículos de matemática das escolas estaduais paulistas e do município de Campinas, onde ocorreu a coleta de dados. As atividades usadas para a adaptação nesta pesquisa foram extraídas dos Cadernos do Aluno do $6^{\circ}$ ano, volume 3 , e do $8^{\circ}$ ano, volume 4 (Secretaria Estadual de Educação, 2009a, 2009b).

O nosso trabalho teve por objetivos iniciais, construir ou adaptar, conforme o caso, aplicar e analisar uma sequência didática, para promover uma aprendizagem adequada a dois alunos com necessidades educacionais especiais, inseridos em uma sala de aula comum, sendo ambos classificados como portadores de paralisia cerebral. Mais detalhadamente, nosso interesse era verificar em que níveis haveria a necessidade de intervir e adaptar os materiais e como isso afetaria a prática da professora-pesquisadora, que atua em uma escola comum com estes alunos. Infelizmente, por motivos de força maior, sua aplicação ficou restrita a apenas uma aluna com paralisia cerebral do $6^{\circ}$ ano, uma vez que o outro não pôde estar presente nas aulas planejadas e aplicadas no $8^{\circ}$.

Outro aspecto que caracteriza esta pesquisa educacional como qualitativa é que temos uma preocupação com o currículo e com a integração efetiva dos alunos com necessidades educativas especiais dentro da sala de aula regular, assim como preocupamo-nos em diferenciar tais necessidades, estudando-as em detalhes durante a prática docente, promovendo a reflexão na ação e avanços em nossa formação continuada. Portanto, o foco desta investigação é a busca da compreensão do ensino regular para alunos com necessidades educativas especiais, baseandonos em fundamentos teóricos para melhorar as nossas práticas pedagógicas, adquirindo mais autonomia para encarar os desafios da escola atual.

Os dois casos estudados envolveram ações preliminares de planejamento, escolha e adaptações de atividades, dos conteúdos e das habilidades a serem 
desenvolvidas, bem como a previsão de interação dos alunos com as atividades e com os colegas de classe. A análise dos dados obtidos com a aplicação em sala de aula pretende responder às seguintes perguntas: $A$ aprendizagem de um aluno com paralisia cerebral é igual à de qualquer outro de sua turma? Como o professor de uma escola regular deve se preparar para integrar alunos com esse tipo de deficiência? O material fornecido pela SEE é suficiente para que se tenha uma educação de qualidade para estes alunos?

\subsection{Caracterização da escola}

A escola onde lecionamos e aplicamos as atividades desta pesquisa é municipal, do Ensino Fundamental, e localiza-se na cidade de Campinas-SP, em um bairro muito antigo, próximo ao centro, cujos moradores do entorno são idosos. Sendo assim, ela possui muitos alunos oriundos de bairros distantes e que, muitas vezes, são filhos de ex-alunos da própria escola.

Ela tem o currículo organizado por ciclos, os quais são divididos da seguinte maneira: ciclo I ( $1^{\circ}, 2^{\circ}$ e $3^{\circ}$ anos); ciclo II ( $4^{\circ}$ e $\left.5^{\circ}\right)$; ciclo III ( $6^{\circ}$ e $7^{\circ}$ ) e ciclo IV ( $8^{\circ}$ e e $9^{\circ}$ anos). O ciclo I e a maioria das salas do ciclo II desenvolvem-se no período da manhã, das 7:30h às 12:30h. No período da tarde, funcionam os ciclos III e IV, com apenas uma sala do ciclo II, das 13:10h às 18:30h. No período noturno, funciona a educação de jovens e adultos (EJA), com $1^{\circ}, 2^{\circ}, 3^{\circ}$ e $4^{\circ}$ termos,compostos por adolescentes a partir dos 17 anos e adultos, até mesmo com 50 anos.

A escola é composta de oito salas de aula, uma sala de vídeo, uma sala de informática, biblioteca e uma sala de recurso, que começou a funcionar em 2012, porém não totalmente, pois não há professor habilitado em todos os horários (a única a trabalhar nesta sala era a professora de educação especial, do período da tarde, que utilizava algumas horas e projetos para atendimento aos alunos da educação especial do período da manhã. Porém esta já foi desligada temporariamente do trabalho nesta sala e não há certeza de seu retorno à função). $O$ atendimento aos alunos deficientes do período da tarde, durante o ano de 2012, foi feito somente durante a aula regular.

A sala de recurso é de funcionamento exclusivo para os alunos da educação especial, no contra turno de seu período escolar regular. Inclui materiais pedagógicos para cegos, alunos com paralisia cerebral e alguns materiais para estudo do corpo 
humano que podem ser usados para alunos com deficiência intelectual e outras. Também possui 'notebook' adaptado para portadores de paralisia cerebral, com 'mouse' também adaptado, uma vez que sua coordenação motora fina é prejudicada.

Os alunos dos ciclos I e II não são avaliados com conceitos e/ou notas, mas com fichas de saberes individuais, que são preenchidas pelos professores trimestralmente. Os alunos dos ciclos III e IV são avaliados por conceitos e classificados em grupo de saberes, que são cinco: o grupo 1 é o dos melhores alunos e o grupo cinco é o dos que não frequentam (as escolas municipais de Campinas têm autonomia para determinar os saberes em cada grupo, que identificam e relacionam o conteúdo assimilado, a competência e habilidades desenvolvidas e observadas no trimestre). As fichas de saberes, nesta classificação, têm espaço para observações individuais e assim podemos relatar o acompanhamento dos alunos com necessidades educacionais especiais nas suas especificidades.

A escola não adota uma apostila, ou um material específico; apenas orienta-se pelo currículo da prefeitura, com seus conteúdos e objetivos para cada ano e ciclo. Logo,os professores, dentro do conteúdo do ciclo, podem utilizar o material que melhor se adapte aos alunos daquele ano, e neste estudo específico, utilizamos as atividades do Caderno do Aluno (São Paulo, 2009), o livro didático escolhido pelos professores e distribuído pelo PNLD-MEC em 2011 (Dante, 2011) e também questões elaboradas junto à orientadora com o uso do software Geogebra.

\subsection{Caracterização dos dois alunos investigados:}

A aluna do 6ํan, a quem chamaremos pelo pseudônimo de Isabela, teve ao nascer um AVC (acidente vascular cerebral), e com isto uma paralisia cerebral, que afetou sua coordenação e deixou sequelas, como um enrijecimento no lado direito do corpo, fazendo com que tivesse dificuldades em seus primeiros anos na escola. Por exemplo, aprendeu a escrever com a mão esquerda em função desse enrijecimento.

Como esta aluna tinha um laudo médico oficial, foi encaminhada a educação especial desde a primeira série, e foi assistida por uma professora especializada desde seu ingresso na escola pública. Ela sempre estudou na mesma escola de ensino fundamental e suas maiores dificuldades em aprendizagem foram trabalhadas durante os primeiros anos escolares, porém apresenta maior lentidão na escrita em 
relação à sua faixa etária. Locomove-se independentemente, porém mais lentamente e com passos irregulares, por apresentar uma perna mais alongada que a outra.

A aluna, que hoje se encontra com quase 15 anos, estava em uma sala de aula de $6^{\circ}$ ano em 2012, onde a média de idade é 11. Ela ficou mais tempo nas séries iniciais para trabalhar suas dificuldades em leitura e escrita. Também usa óculos e chega a encostar a cabeça no caderno ao escrever, para compensar problemas de visão (miopia); senta sempre nas primeiras carteiras.

O aluno do $8^{\circ}$ ano, e que chamaremos pelo pseudônimo de Miguel, teve paralisia cerebral ao nascer e o diagnóstico é: "Encefalopatia Crônica não progressiva da infância ou Paralisia Cerebral".

Esta anomalia é entendida como resultado de uma lesão ou mau desenvolvimento do cérebro, de caráter não progressivo, porém permanente e existindo desde a infância. A deficiência motora se expressa em padrões anormais de postura e movimentos, associados a tônus postural anormal. A lesão que atinge 0 cérebro quando é imaturo interfere no desenvolvimento motor da criança. Assim sendo, a lesão cerebral pode comprometer a locomoção, postura, movimento, uso das mãos, a linguagem entre outras atividades. Os movimentos podem ser reduzidos, pode ocorrer a espasticidade, falta de marcha e a linguagem pode não existir ou ser deficitária. A cognição, por sua vez, nem sempre está comprometida, porém em alguns casos, a lesão do sistema motor pode afetar o cérebro, originando a deficiência mental (Brasil, 2006, 2007).

Neste aluno, os movimentos são reduzidos e sua linguagem é deficitária. A parte cognitiva parece não ter sido muito abalada, pois ele tem reações com algumas atividades escolares que demonstram sua capacidade. Por exemplo: ele compreende as falas do professor, as orientações das tarefas e as anedotas dos colegas e consegue executar algumas atividades escolares, desde que utilize o 'notebook' e o 'mouse' adaptado. Então, uma das necessidades básicas para este aluno é o desenvolvimento da sua comunicação. Para tanto, deverão ser utilizadas as Tecnologias Assistivas, ou seja, aquelas de característica interdisciplinar, que englobam produtos, recursos, metodologias, estratégias, práticas e serviços que objetivam promover a funcionalidade, relacionada à atividade e participação de pessoas com deficiência, incapacidades ou mobilidade reduzida, visando sua autonomia, independência, qualidade de vida e inclusão social. 


\section{Capítulo III - A Construcão do Plano de Ensino}

Neste capítulo, relataremos o estudo realizado sobre as Propostas Curricular do Estado de São Paulo e as Diretrizes Curriculares da Educação Básica do Município de Campinas e vamos apresentar o plano de ensino com as atividades adaptadas e as adicionadas, que foram desenvolvidas nas salas de aula.

\subsection{Habilidades e conteúdos para 0 60 e $8^{\circ}$ anos do Ensino}

\section{Fundamental}

\subsubsection{Proposta Curricular do Estado de São Paulo}

Nesta proposta, os elaboradores consideram que a Matemática, juntamente com a língua materna, constituem dois componentes básicos dos currículos escolares, pois a função da escola é ensinar a "ler, aprender e contar" (São Paulo, 2012 p.25) isto é, a promover uma dupla alfabetização no universo das letras e dos números.

A área de Matemática é apresentada como um campo separado das Linguagens e Códigos e das Ciências da Natureza, pois se considera que ela tenha uma linguagem própria muita rica em ideias e objetos específicos, como os números e as operações, as formas geométricas e as relações. Uma outra razão para isto seria que a linguagem materna nem sempre supre as necessidades em alguns textos matemáticos, e vice-versa: "os alunos devem ser conduzidos a apreciar a beleza presente tanto na exatidão dos cálculos quanto no rigor expressivo do texto poético".

E ainda, uma terceira razão para o tratamento da Matemática como área específica é a possibilidade de tal opção facilitar a incorporação crítica dos inúmeros recursos tecnológicos que existem atualmente, para a representação de dados e tratamento das informações disponíveis, na busca da transformação de informação em conhecimento (São Paulo, 2012, p.27).

Ainda nessa área, consideram que a ideia de contextualização é importante, porém que esta deva ser equilibrada com o desenvolvimento da capacidade de abstração dos alunos e com a capacidade de imaginar situações que não existem concretamente. É esta questão de abstração que se encontra mais efetivamente no conteúdo da Matemática. 
A linguagem matemática também se enquadra nos três eixos norteadores da ação educacional, que são considerados competências básicas a serem desenvolvidas pelo aluno, ao longo do ensino básico, quais sejam: expressão/compreensão, argumentação/decisão, contextualização/abstração (São Paulo, 2012).

Em relação ao primeiro eixo, temos que a Matemática compõe, junto com a língua materna, um meio de expressão e de compreensão da realidade. Os objetos matemáticos (números, formas, relações), constituem instrumentos básicos para essa compreensão, pois utilizamos desde a leitura de um texto ou a interpretação de um gráfico, até a apreensão quantitativa das grandezas e relações presentes em fenômenos naturais ou econômicos. Com relação ao eixo argumentação/decisão, temos na matemática instrumentos para o desenvolvimento do raciocínio lógico, da análise racional e da resolução de problemas. No que se refere ao terceiro eixo, como já mencionado, ela é uma disciplina bastante adequada e até privilegiada para se aprender a lidar com os elementos do par concreto/abstrato.

Ainda segundo a Proposta Curricular do Estado (São Paulo, 2012), os temas matemáticos terão como partida a realidade do aluno, porém não se pode privá-los de significados epistemológicos e culturalmente relevantes construídos dentro dessa área do conhecimento. Então, há a necessidade de uma relação direta entre todos os temas tratados em sala de aula e os contextos concretos ou abstratos em que eles estão envolvidos.

A Matemática também se apropria de tecnologias para seu desenvolvimento como, calculadoras, computadores, softwares, e deve-se observar que seu crescente uso é inevitável e desejável, salvo em condições extraordinárias e em razão de extremo mau uso. Do ponto de vista curricular, esta disciplina escolar deve articularse permanentemente com todas as formas de expressão, especialmente com as associadas às tecnologias informáticas, colaborando com uma tomada de consciência da ampliação de horizontes que essas novas ferramentas propiciam. Os conteúdos da disciplina de Matemática não devem ser apenas considerados em si mesmos, mas também como um meio para o desenvolvimento de competências, tais como: capacidade de expressão pessoal, de compreensão de fenômenos, de argumentação consistente, de tomada de decisões conscientes e refletidas, de problematização e enraizamento dos conteúdos estudados em diferentes contextos,e de imaginação de novas situações. Como a lista de conteúdos é muito extensa e nem 
sempre muito significativa, o professor precisa estar atento ao fato de que a lista de ideias matemáticas fundamentais a serem exploradas não é tão extensa e que estas são fundamentais no estudo de grande diversidade de assuntos. Proporcionalidade, equivalência, ordem, aproximação são exemplos disso. O reconhecimento e a caracterização das ideias fundamentais, pelo professor, faz com que possibilite uma articulação natural entre os diversos assuntos, numa espécie de "interdisciplinaridade interna". E também, uma ideia realmente fundamental ultrapassa o limite da disciplina, favorecendo uma aproximação no tratamento dos temas de diversas outras como: Química, Física, Biologia, Geografia, etc (São Paulo, 2012).

Por esses motivos, como já mencionado, os conteúdos de matemática, nessa Proposta, são organizados em três grandes blocos temáticos: Números, Geometria e Relações. Estas últimas incluem a noção de medida, com a riqueza da ideia de aproximação, as relações métricas em geral e as relações de interdependência, como as de proporcionalidade, ou as associadas à ideia de função. Os conteúdos dos três blocos se relacionam permanentemente, sendo impossível abordar um deles sem a participação dos outros.

A Proposta salienta que cada tema deve ser apresentado de uma maneira especialmente significativa do ponto de vista de seu valor formativo e construir uma articulação entre os diversos temas e disciplinas. Os conteúdos são nela apresentados por bimestre, havendo, assim, dois ou mais temas dominantes que servem para o desenvolvimento dos demais. As ideias fundamentais é que devem estar em foco, sendo importante que o professor apresente o que for possível em cada bimestre: é preferível tratar um pouco de cada um deles, a passar o ano inteiro explorando um único assunto.

Esse documento destaca 0 papel decisivo representado pelas aulas expositivas, mas salienta que o professor não pode limitar-se a esta forma. Muitos outros recursos devem ser utilizados, incluindo os das tecnologias informáticas.

A seguir, apresentamos um quadro de conteúdos e habilidades de Matemática para o 6a ano do Ensino Fundamental, segundo a Proposta Curricular do Estado de São Paulo:

\begin{tabular}{|ll|}
\hline & $5^{\text {a }}$ série/60 Ano do Ensino Fundamental \\
\hline & $1^{\circ}$ bimestre \\
\hline Números & Conteúdos \\
\hline
\end{tabular}


Números Naturais

- Múltiplos e Divisores

- Números Primos

- Operações Básicas ( +, -, ., ‘)

- Introdução às potências

Frações

- Representação

- Comparação e ordenação

- Operações

\section{Habilidades}

- Compreender as principais características do sistema decimal: significado da base e do valor posicional

- Conhecer as características e propriedades dos números naturais: significado dos números primos, de múltiplos e divisores.

- Saber realizar operações com números naturais de modo significativo (adição, subtração, multiplicação, divisão, potenciação)

- Compreender o significado das frações na representação de medidas não inteiras e da equivalência de frações

- Saber realizar as operações de adição e subtração de frações de modo significativo.

\section{$2^{\circ}$ bimestre}

\section{Conteúdos}

\section{Números /Relações}

Números decimais

- Representação

- Transformação em fração decimal

- Operações

Sistema de medidas

- Medida de comprimento, massa, e capacidade

- Sistema métrico decimal: múltiplo e submúltiplos da unidade Habilidades

- Compreender o uso da notação decimal para representar quantidades não 


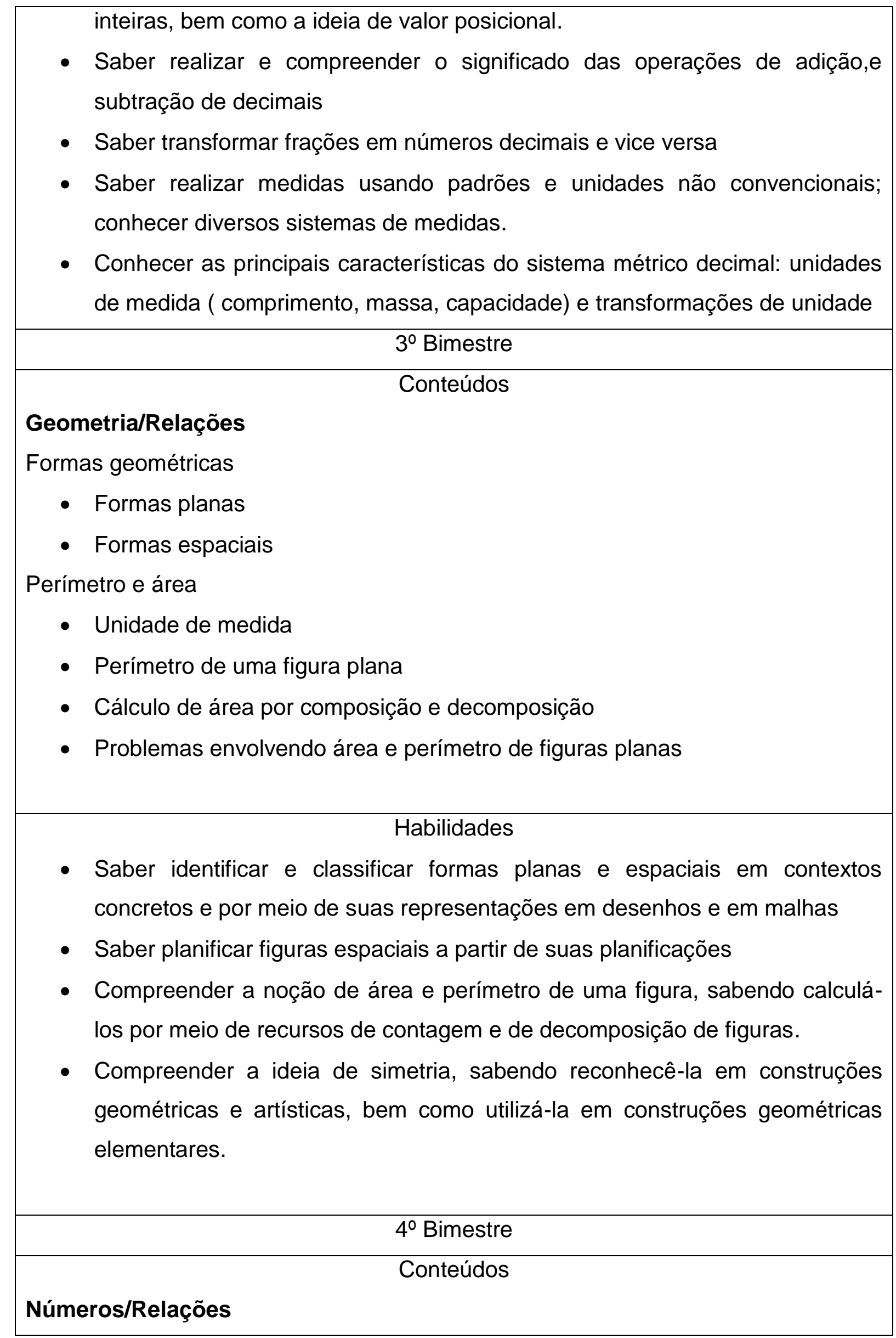


Estatística

- Leitura e construção de gráficos e tabelas

- Média aritmética

- Problemas de contagem

\section{Habilidades}

- Compreender informações transmitidas em tabelas e gráficos

- Saber construir gráficos elementares (barra,linha,pontos) utilizando escalas adequadas

- Saber calcular, interpretar e utilizar informações relacionadas às medidas de tendência central (média, mediana, moda)

- Saber utilizar diagramas de árvore para resolver problemas simples de contagem

- Compreender a ideia do principio multiplicativo de contagem

Quadro de conteúdos e habilidades para o 6º ano (São Paulo, 2012).

\section{7ª série/8을 Ano do Ensino Fundamental}

\section{$1^{\circ}$ bimestre}

Conteúdos

\section{Números}

Números racionais

- Transformação de decimais finitos em fração

- Dízimas periódicas e fração geratriz

Potenciação

- Propriedades para expoentes inteiros

- Problemas de contagem

\section{Habilidades}

- Compreender a ideia de número racional em sua relação com as frações e as razões

- Conhecer as condições que fazem com que uma razão entre inteiro possa se expressar por meio de dízimas periódicas; saber calcular geratriz de uma dízima

- Compreender a utilidade do uso da linguagem das potências para 


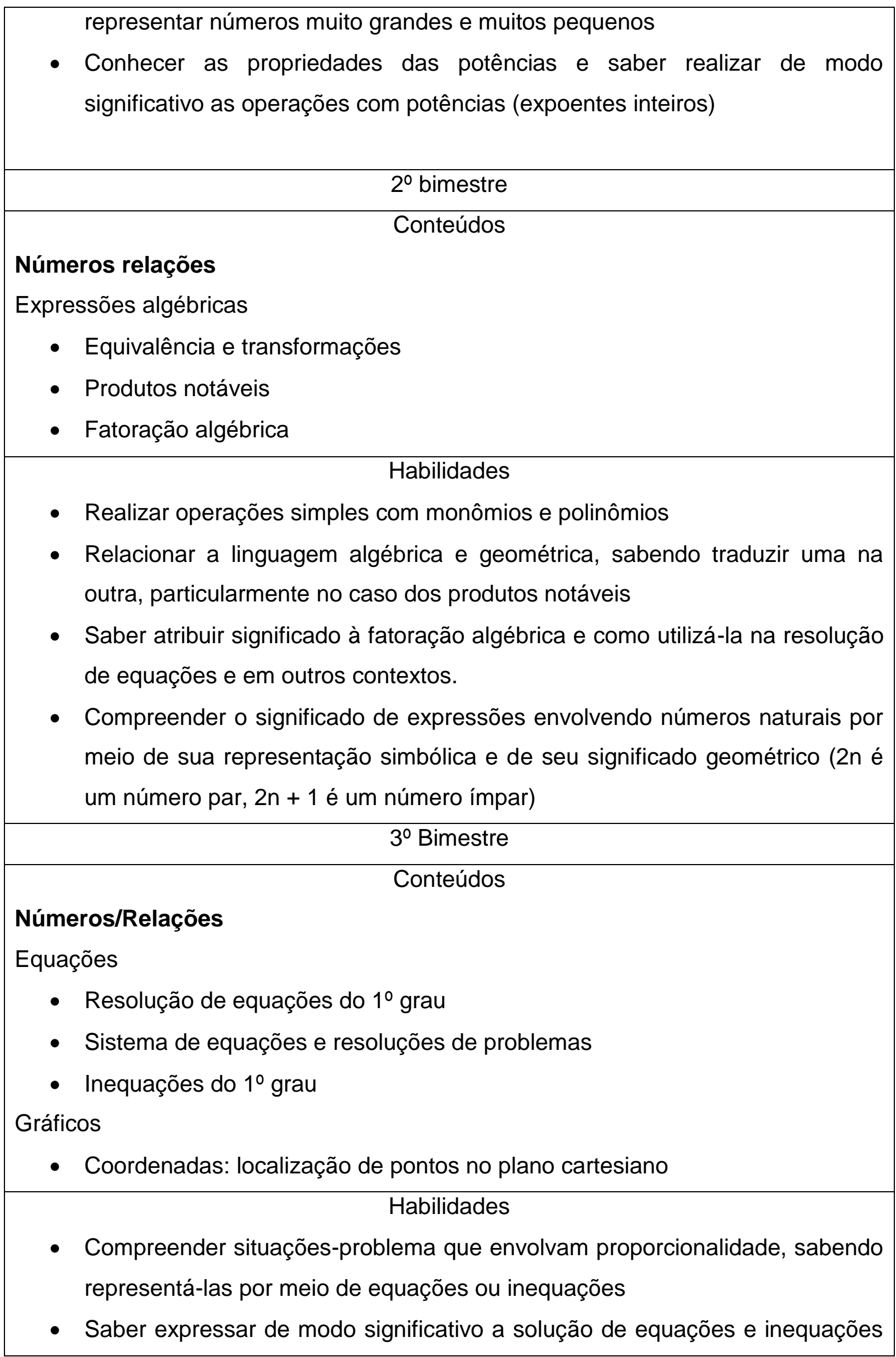




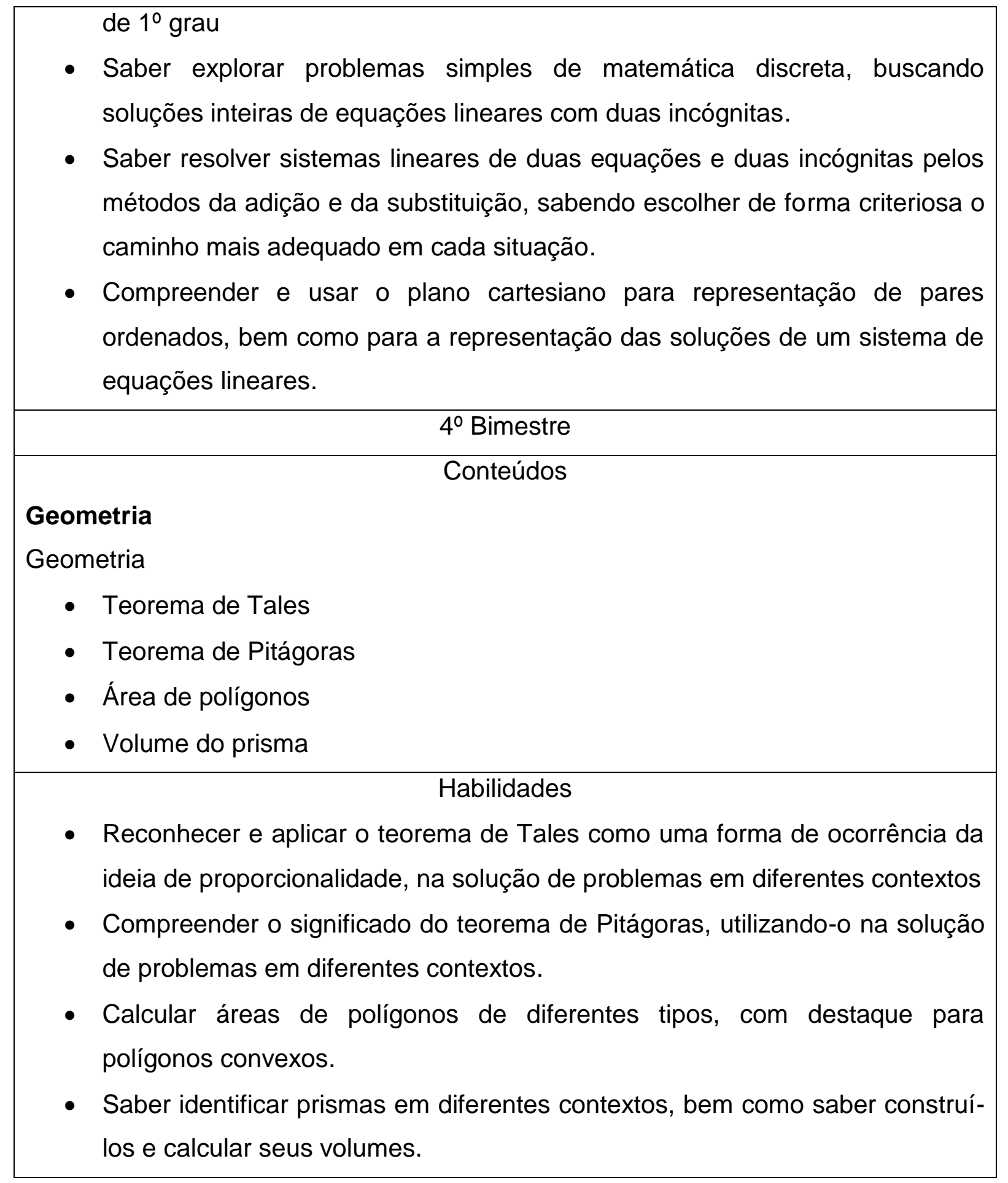

Quadro de conteúdos e habilidades para o 8ํano (São Paulo, 2012). 


\subsubsection{Diretrizes Curriculares de Matemática da Prefeitura de}

\section{Campinas}

As Diretrizes Curriculares da Prefeitura de Campinas (Campinas, 2010) foram elaboradas com a participação de professores no I Seminário Curricular, ocorrido em agosto de 2010, e que levaram a discussão dos temas às escolas. Pretendia-se, com esse documento, encontrar uma proposta para a realidade dos alunos da rede municipal.

A preocupação era a de estabelecer competências e definir objetivos que iriam ajudar os jovens em seu exercício da cidadania. Porém, o documento ressalta que se deve estabelecer conteúdos que contribuirão para o desenvolvimento de habilidades matemáticas, influenciando os alunos a entender o processo de ensino e aprendizagem da disciplina. Aponta a importância dos professores utilizarem a História da Matemática e a Etnomatemática, na busca de caminhos e procedimentos para o trabalho com as diferenças. Então, o trabalho em sala de aula deve contemplar as múltiplas vivências e as aulas devem se utilizar de recursos e instrumentos acessíveis a todo tipo de público (Campinas, 2010).

$O$ documento enfatiza, ainda, que o uso de recursos tecnológicos, como computadores, calculadoras e jogos, auxiliam nas diferentes atividades, levando a Matemática a ficar mais próxima do cotidiano, pois permite a utilização correta das notações e explora maneiras diferentes de cálculos, estimulando, assim,a estimativa e a conferência de resultados.

Segundo essas diretrizes, devem ser observados oito objetivos por ano para o ciclo $\mathrm{III}^{1}$ e ciclo IV, cabendo ao professor adequá-los a sua realidade e sempre pensando nos níveis de saberes dos alunos envolvidos.

\begin{tabular}{|c|}
\hline Diretrizes Curriculares do Município de Campinas para o ciclo III \\
\hline Objetivos gerais para o Ciclo III \\
\hline C Compreender o que significam os diferentes tipos de números
\end{tabular}

\footnotetext{
${ }^{1}$ As escolas municipais de Campinas têm seu ensino em ciclo de aprendizagem, onde a separação é feita da

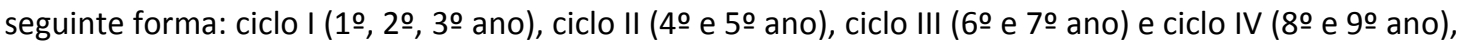
atualmente é diferente dos ciclos das escolas estaduais de São Paulo, que consiste em dois ciclo I (1으o 5 음 ano) e ciclo II (6ํano, 6a, 7 a, $8^{a}$ série).
} 


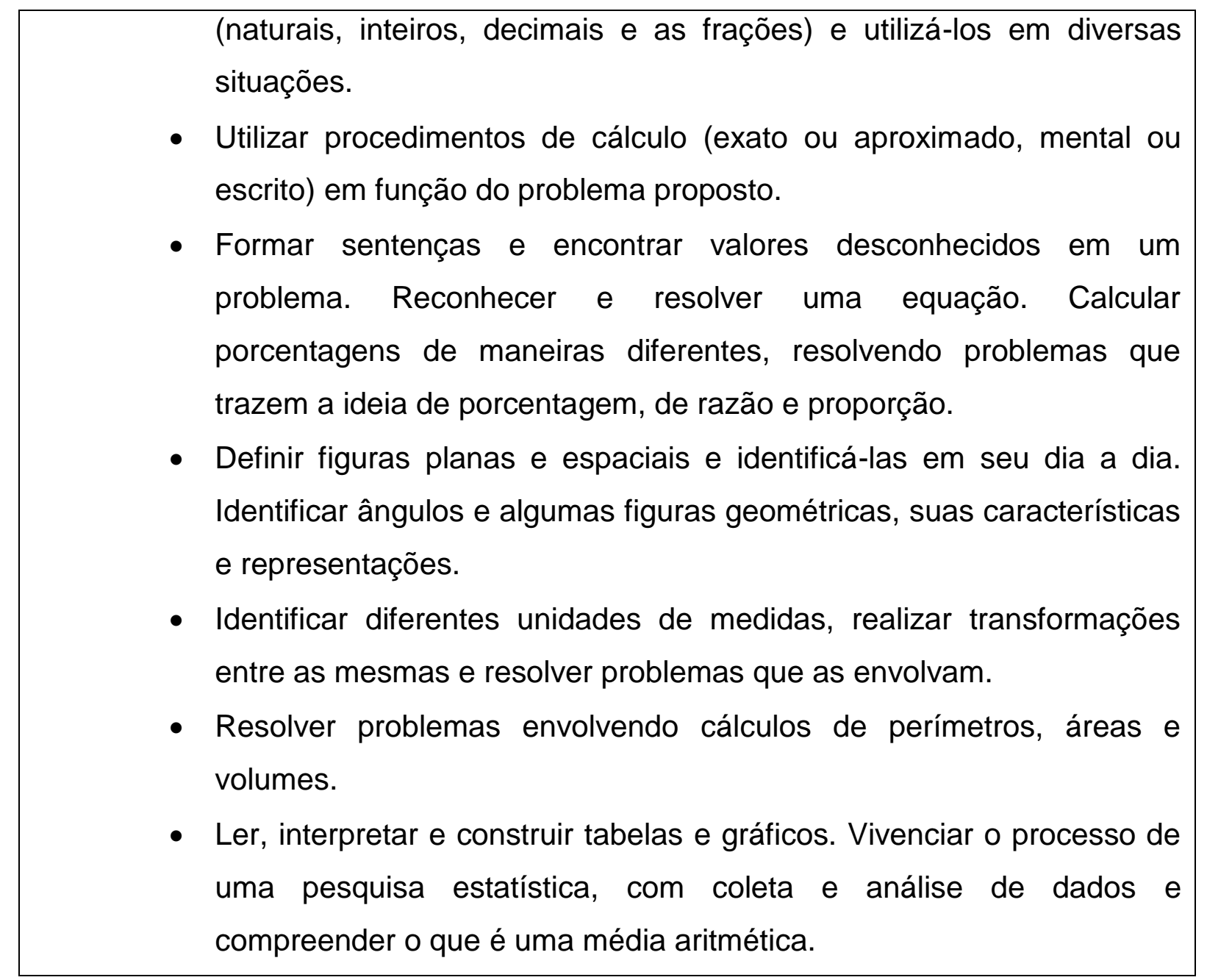

Quadro dos objetivos para o ciclo III (6ํㅜ e $7^{\circ}$ anos), (Campinas, 2010).

\section{Objetivos Específicos \\ 6 Ano}

- Explorar os números em situações de contagem, de possibilidades de ordenação e de cálculos (adição, subtração, multiplicação, divisão, potenciação), compreendendo as regras do nosso sistema de numeração decimal, utilizando diferentes materiais e instrumentos.

- Resolver situações-problema que permitam transferir para a sala de aula as suas vivências.

- Compreender como uma sequência numérica é formada e construir uma sequência de números, de figuras, etc. Usar os múltiplos e divisores de um número em diferentes situações do cotidiano. Identificar um número primo. 
- Utilizar os números decimais (representações com vírgula) e em forma de frações e porcentagens, para cálculos e para resolver problemas do dia a dia, utilizando-os para ler e interpretar diferentes informações.

- Identificar as diferentes formas geométricas encontradas na natureza e em seu dia a dia, por meio da observação e exploração do espaço, desenvolvendo sua percepção visual e compreendendo o conceito de ângulo, utilizando as noções de giro, direção e sentido.

- Definir figuras planas e espaciais e identificá-las em seu dia a dia, reportando-se em alguns momentos à consulta de obras de arte e livros de História, a fim de observar como as formas geométricas foram sempre usadas nas construções humanas.

- Utilizar diferentes unidades de medidas e alguns instrumentos de medição; resolver problemas em que elas apareçam e reconhecer as unidades envolvidas em situações de medição de tempo, demarcação de espaço, etc.

- Compreender o que é, e como é realizada, uma pesquisa de opinião, traduzindo-a em tabelas, gráficos e na produção de textos, comunicando a análise de seu resultado.

Quadro com os oito objetivos para o 6 ano (Campinas, 2010).

\section{Diretrizes curriculares do Município de Campinas para o ciclo IV} Objetivos gerais para o Ciclo IV

- Aprofundar os conhecimentos sobre os números, principalmente aqueles com vírgula e fracionários, para conhecer onde e como são usados, além de resolver problemas nos quais eles estarão presentes.

- Resolver problemas envolvendo as quatro operações fundamentais e, a partir de agora a potenciação e a radiciação.

- Identificar e resolver equações de $1^{\circ}$ e $2^{\circ}$ graus, inequações e sistemas de equações. Resolver problemas envolvendo estes tipos de equações, podendo também criar maneiras próprias para isso. 
- Reconhecer e trabalhar com figuras geométricas planas.

- Reconhecer a diferenciação entre figuras bidimensionais e tridimensionais e resolver problemas que envolvam o cálculo de áreas e volumes das mesmas.

- Conhecer uma função de $1^{\circ}$ grau e construir um gráfico para representá-la.

- Resolver problemas que envolvam diferentes grandezas, utilizando-se de diferentes estratégias para tanto, inclusive dos processos envolvendo a regra de três.

- Compreender diferentes termos usados na Estatística (frequência, moda, média aritmética) e utilizá-los. Calcular a possibilidade de acontecimento de um evento.

\section{Objetivos específicos}

8응 Ano

- Utilizar números primos para o cálculo do mínimo múltiplo comum, para decomposição em fatores primos e para resolver problemas.

- Operar frações de diferentes tipos em situações variadas.

- Resolver problemas que envolvam o uso da regra de três em situações envolvendo proporção, cálculos de desconto e acréscimos.

- Reconhecer, identificar, diferenciar e resolver expressões algébricas, equações de $1^{\circ}$ grau e inequações de $1^{\circ}$ grau.

- Compor e resolver sistemas de equações de $1^{\circ}$ grau a partir de situações do cotidiano.

- Resolver problemas que abordam diversos conceitos geométricos e relações determinadas entre os ângulos de um quadrilátero e de polígonos e realizar a soma dos ângulos internos de um triângulo qualquer.

- Calcular áreas de superfícies planas tais como paralelogramos, triângulos, losangos e trapézios por meio de uso de fórmulas.

- Resolver problemas utilizando noções de escala e analisar plantas e mapas, identificando as escalas utilizadas.

- Resolver problemas que envolvam as várias possibilidades de acontecer uma situação utilizando o cálculo de porcentagens e elaborar problemas a 
partir de diferentes textos envolvendo o uso da porcentagem em situações variadas.

Quadro com os oito objetivos para o ciclo IV e específico para o $8^{\circ}$ ano (Campinas, 2010).

\subsection{Atividades escolhidas}

\subsubsection{O plano de ensino para o 6ano A}

A atividade desenvolvida para esta série foi sobre geometria, a partir de ideias do Caderno do Aluno do terceiro bimestre (São Paulo, 2009).

Segundo a Proposta Curricular da Secretaria da Educação do Estado de São Paulo (São Paulo, 2012), em Geometria se estuda: percepção de formas; relação entre elementos de figuras planas e espaciais; construção de formas geométricas;elaboração e concepção de espaço que sirvam de suporte para a compreensão do mundo físico que nos cerca.

A dinâmica do trabalho desta pesquisa era estudar a Proposta Curricular do Estado de São Paulo, selecionar atividades que pudessem ser usadas com os alunos com paralisia cerebral e verificar se era necessário adequá-las a esses alunos. Como a atividade seria aplicada a uma aluna da Prefeitura de Campinas, foi necessário estudar as diretrizes que a escola seguia para a elaboração do plano de ensino.

Foi escolhido, do Caderno do Aluno de Matemática (São Paulo, 2009) -5ª série/6 ${ }^{\circ}$ ano- volume 3, a situação de aprendizagem 1- Definir e Classificar experimentando, pois a classe já havia estudado Geometria espacial no segundo trimestre, e pelo planejamento anual, este seria o momento da geometria plana. Nesta atividade, os alunos formariam grupos, sem a interferência da professora, a qual verificaria apenas como eles iriam se organizar e principalmente se relacionar com a aluna da educação especial.

Por ser uma atividade que usa a vivência do aluno, observaria como eles (alunos com e sem deficiência) lidam com a parte matemática encontrada em seu dia a dia e também se estes iriam fazer relações com conteúdos já estudados.

Os alunos da sala investigada, 6ำ ano A, apresentavam dificuldade na escrita, verificadas pela professora de Língua Portuguesa. A atividade selecionada também 
daria uma visão de como eles, inclusive a aluna Isabela, se comunicariam, pois previa a interação oral e escrita.

Mesmo se tratando de uma atividade a ser aplicada a aluna com paralisia cerebral, julgamos que não seriam necessárias mudanças na sequência que aparecia na proposta do Estado ( São Paulo, 2009).

A seguir, apresentaremos o plano originalmente escolhido para a sala investigada ( $6^{\circ}$ ano A), visando atender aos objetivos das Propostas Curriculares citadas e às especificidades da turma:

\section{Plano de Ensino do 60 ano}

Objetivos:

Levar o aluno a compreender as características das figuras geométricas planas, através da troca de experiência em pequenos grupos. Levá-lo a fazer distinções entre figuras planas, semelhantes ou não, através da observação de suas similaridades e diferenças.

\section{Conteúdos e Temas:}

Elementos, classificação e propriedades das figuras planas.

\section{Competências e Habilidades}

Estabelecer critérios de classificação; reconhecer elementos geométricos que podem caracterizar uma figura.

Tempo estimado: cinco aulas de 50 minutos cada.

Material necessário: Xerox da atividade, lápis, régua, dicionário, livro didático ( Dante, 2011). 


\section{Desenvolvimento}

1a etapa:

Separar os alunos em pequenos grupos (com quatro pessoas), conforme indicação do Caderno do Aluno (São Paulo, 2009) e disponibilizar formas de figuras planas diversificadas, onde cada membro do grupo deverá escolher uma figura ao acaso e descrever para os demais uma ou duas características que tenha chamado sua atenção.

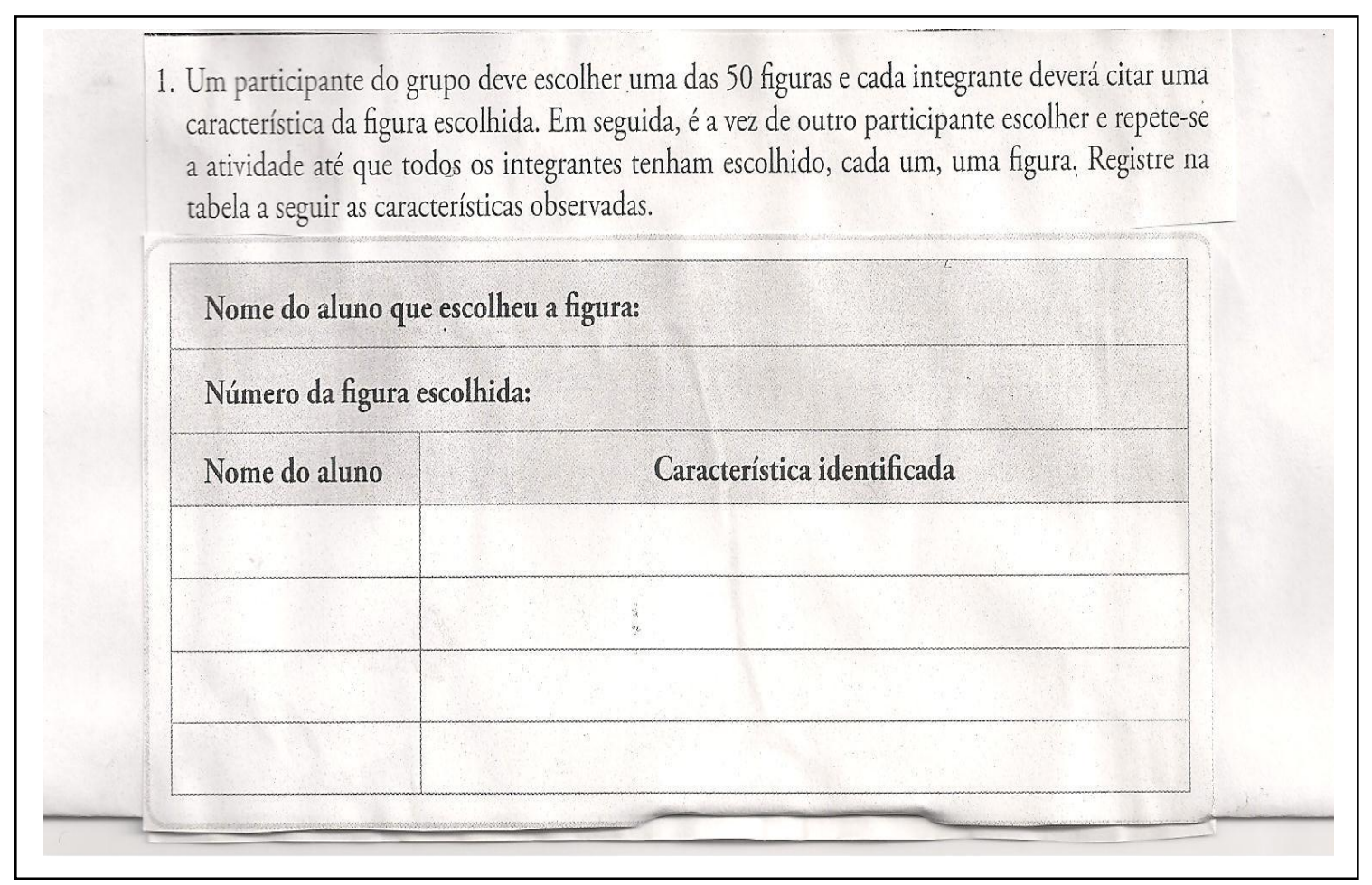


2a etapa:

Um dos alunos do grupo irá escolher uma nova figura e dar uma característica a ela, e o outro deverá procurar figuras com a mesma característica para compor um conjunto.

2. Cada integrante do grupo deve escolher uma figura e citar uma de suas características. Em seguida, todos os outros integrantes do grupo devem listar quais das 50 figuras têm a característica escolhida. Cada um deverá preencher a tabela a seguil.

\begin{tabular}{|c|c|}
\hline Nome do aluno & \\
\hline $\begin{array}{c}\text { Número da figura e } \\
\text { característica escollhida }\end{array}$ & \\
\hline Número das figuras com & \\
a característica escolhida & \\
\hline
\end{tabular}




\section{3a etapa:}

Utilizando o número das figuras, identificar aquelas com as características já pré estabelecidas.

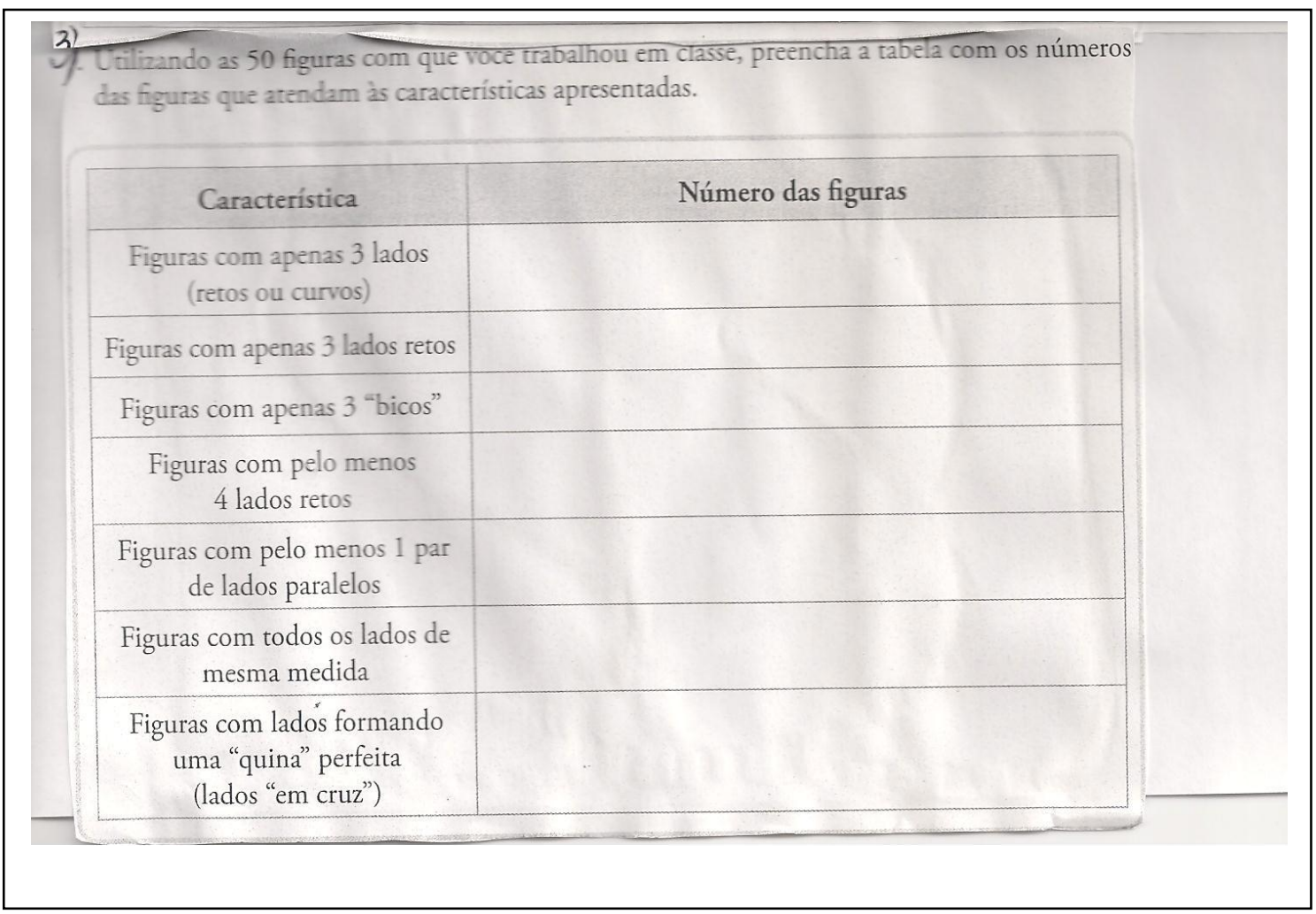


4a etapa:

Estabelecer correspondência entre as nomenclaturas "oficiais" da matemática e a descrição feita pelo aluno nas etapas anteriores.

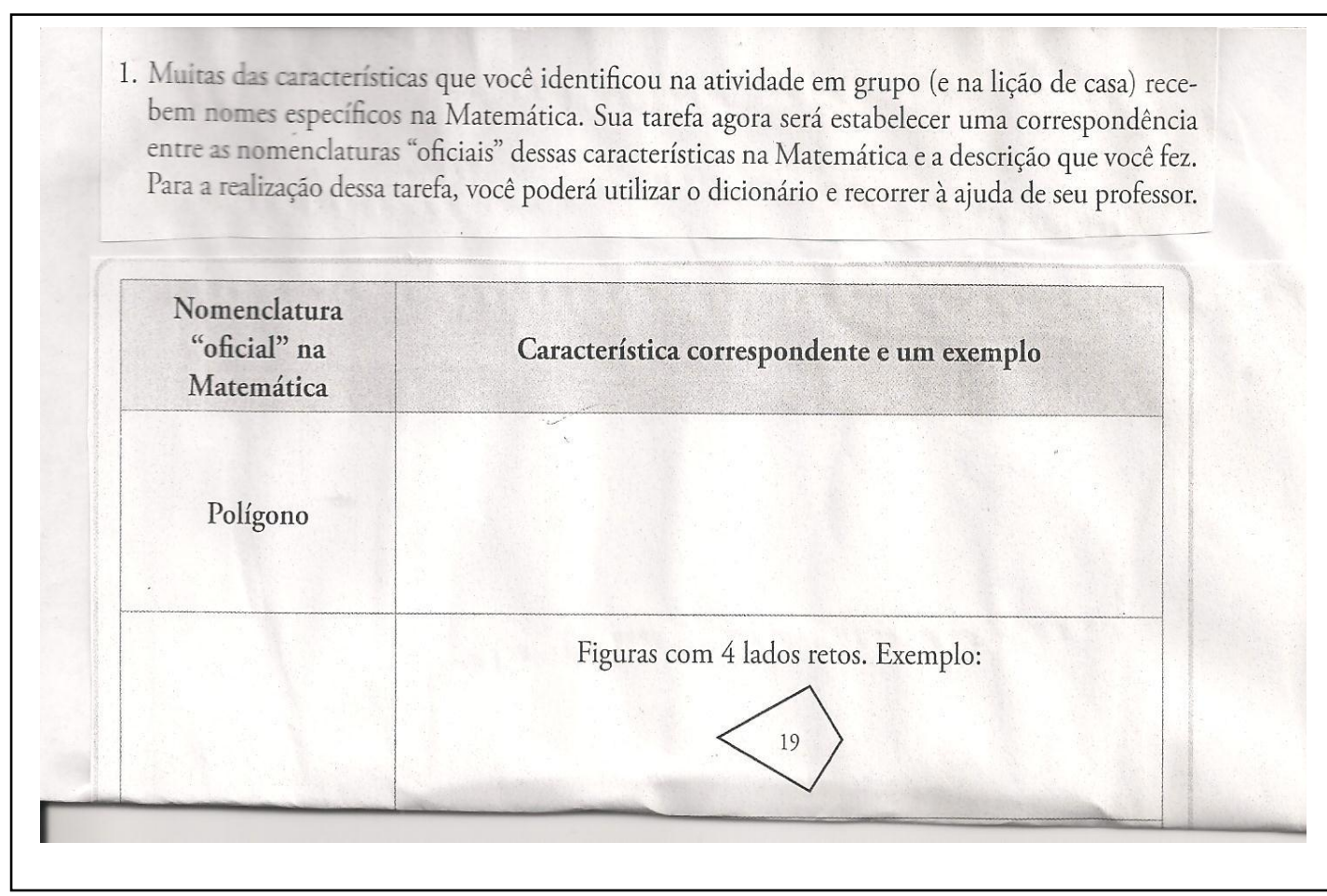

5⿳亠口冋 etapa:

Correção, comentário e também registro de outras definições geométricas dadas pelo professor, no espaço previsto na folha da atividade da $4^{\underline{a}}$ etapa.

\section{Avaliação}

Serão observadas a organização dos grupos, a participação oral dos componentes e a escrita produzida ao final de cada etapa da atividade. 


\subsubsection{0 plano de ensino para o 8 ano A:}

Durante o segundo trimestre, foram trabalhados com os alunos os temas de porcentagem e números diretamente e inversamente proporcionais. No terceiro trimestre, introduziríamos, no estudo de geometria, a razão entre segmentos, chegando ao teorema de Tales.

A atividade do Caderno do Aluno (São Paulo, 2009(b)), 8o ano volume 4 situação de aprendizagem 2: "Teorema de Tales: A proporcionalidade na Geometria'traz o enunciado deste teorema: "Se um feixe de retas paralelas, indicado pelas retas $\mathbf{a}, \boldsymbol{b}$ e c , é interceptado por duas retas transversais, $\boldsymbol{d}$ e e, então os segmentos determinados pelas paralelas sobre as transversais são proporcionais" (São Paulo, 2009(d)). Porém, antes de aplicá-la, seria necessário discutir com os alunos a importância de se compreender esse teorema.

Como os alunos não tinham familiaridade com demonstrações, seria necessário fazer a constatação do teorema de Tales usando a experimentação e com isto,propusemos a construção de retas paralelas, retas transversais e a medição dos segmentos que se formavam.

A proposta era fazer esta construção primeiramente no caderno, usando a própria linha e régua. Após isto, propusemos utilizar, na sala de informática, o software Geogebra para facilitar a construção e mostrar aos alunos que há instrumentos facilitadores para o entendimento.

Para a realização dessa parte da atividade, seria necessário também adaptar o computador do aluno Miguel, para o uso do software, pois este não vem com ele instalado. $\mathrm{O}$ aluno tem um mouse adaptado à sua deficiência motora, o que faz com que seja impossível, para ele, o uso da régua. Assim, o software Geogebra foi o recurso encontrado para adaptar a atividade para atender às dificuldades desse aluno e, ao mesmo tempo, ajudar a fixar os conceitos para os demais.

Segue o plano de ensino para o $8^{\circ}$ ano, que foi aplicado na sala de aula. Porém destacamos que esta aplicação se deu sem a presença do Miguel, pois por motivo particulares, não foi à escola no último trimestre (a avó, que o levava para as aulas, estava impedida de fazê-lo). Mas ele continua sendo aluno da escola e poderá assim, vivenciá-la em outra oportunidade. 


\section{Plano de Ensino do 8 ano A:}

Objetivos:

Explorar as razões constantes presentes nas figuras geométricas semelhantes, desenvolvendo a noção de proporcionalidade; estudar a semelhança de figuras de forma intuitiva, explorando o conceito de retas paralelas.

Conteúdos e Temas:

Semelhança e proporcionalidade; razões; teorema de Tales.

Competências e Habilidades

Identificar situações em que existe ampliação/redução proporcional em figuras; explorar relações entre elementos geométricos; desenvolver a capacidade de síntese e generalizações.

Ano: 8ำ Ano

Tempo estimado: 10 aulas de 50 minutos cada

Material necessário: Xerox da atividade, lápis, régua, computador (e o 'notebook' e o 'mouse' adaptado para o aluno com paralisia cerebral), software Geogebra.

\section{$\underline{\text { Adaptação }}$}

Construção de um material para desenvolver a introdução do conceito de proporcionalidade entre retas paralelas e transversais. Usar o computador e o mouse adaptado à deficiência do aluno, com o software Geogebra,para relacionar elementos geométricos. 
Desenvolvimento

$1^{\text {a }}$ etapa

Desenvolver a atividade introdutória em sala de aula e com o auxílio do computador (Geogebra). Usar também a calculadora do computador para fazer as divisões necessárias.

1- Desenhar, utilizando as linhas do caderno, três retas paralelas.

2- Desenhar duas retas transversais cortando estas paralelas.

3- Marcar os pontos das intersecções das retas utilizando letras maiúsculas.

4- Completar a tabela:

\begin{tabular}{|l|l|}
\hline \multicolumn{1}{|c|}{ Segmento } & \multicolumn{1}{c|}{ medidas } \\
\hline$A B$ & \\
\hline$B C$ & \\
\hline$A C$ & \\
\hline DE & \\
\hline EF & \\
\hline DF & \\
\hline
\end{tabular}

5- Completar a tabela com as razões:

\begin{tabular}{|l|l|}
\hline \multicolumn{1}{|c|}{ Razões } & Resultado da divisão \\
\hline$A B / B C$ & \\
\hline$A B / A C$ & \\
\hline$D E / E F$ & \\
\hline$D E / D F$ & \\
\hline
\end{tabular}

6- Observar e anotar o que aconteceu com o resultado das divisões da tabela do exercício 5. 
$2^{\text {a }}$ etapa

O aluno deverá comparar a atividade feita em sala de aula e na informática, se preparando para as atividades do Caderno do Aluno.

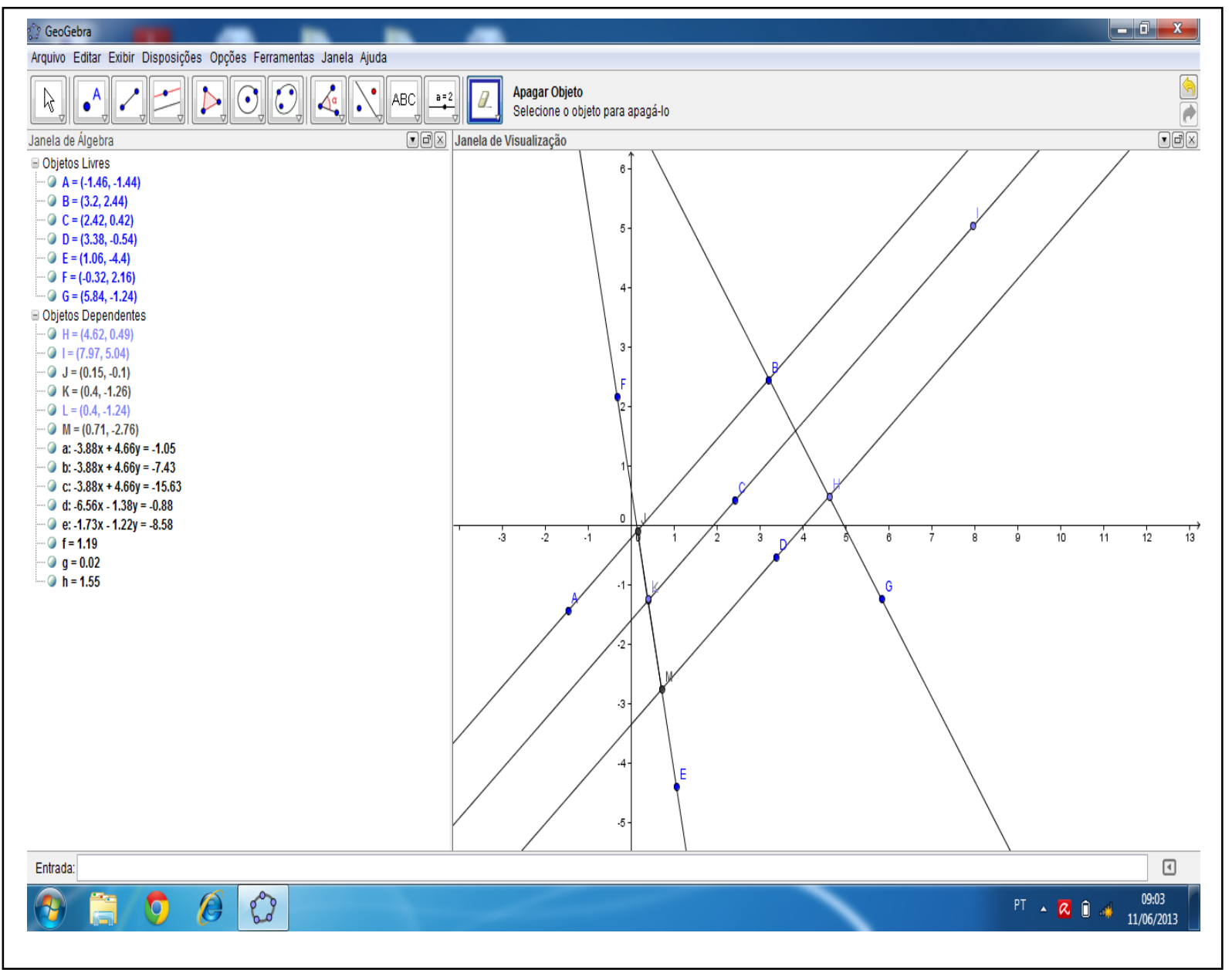

Tela do Geogebra utilizada nas atividades.

As etapas 1 e 2 não faziam parte do Caderno do Aluno (São Paulo, 2009(b)) e foram desenvolvidas por esta professora pesquisadora. 
$3^{\text {a }}$ etapa

Desenvolver as atividades do Caderno do Aluno da situação de aprendizagem 2 Teorema de Tales. (atividade 1, 2, 3, 4, 5 e 6), fazendo os cálculos, usando a calculadora quando necessário e assim utilizando o teorema que aprendeu.

Nesta atividade espera-se que o aluno identifique o Teorema de Tales e use as proporcionalidades dos segmentos.

$4^{\mathrm{a}}$ etapa

Correção, comentário feito pelo professor das atividades do Caderno do Aluno, sintetizando as ideias principais sobre o uso da proporção no Teorema de Tales.

\section{$\underline{\text { Avaliação }}$}

Será observado o uso da régua para fazer as medidas no caderno, o uso do computador (Geogebra) como instrumento facilitador, e para verificar se a atividade construída anteriormente foi suficiente para desenvolver o que era proposto no Caderno do Aluno (São Paulo, 2009). 


\section{Capitulo IV- Análise da Aplicação das Atividades}

Como o foco desta investigação era a busca de compreensão da inclusão de alunos portadores de paralisia cerebral no ensino regular, foi aplicada a sequência didática do 60 ano $\mathrm{A}$ com a presença da aluna Isabela. Era nossa intenção aplicar a sequência do $8^{\circ}$ ano A quando 0 aluno Miguel pudesse estar presente, porém isto não foi possível ainda em 2012. Assim, decidimos desenvolver tal sequência mesmo sem sua presença, a fim de avaliar os benefícios que ela poderia trazer na integração de todos os demais alunos com aprendizagem do Teorema de Tales.

A seguir, apresentaremos uma análise de cada uma destas experiências.

\section{1- Atividade aplicada no 6을 A}

Durante o segundo trimestre, já havíamos trabalhado com Geometria espacial, dando ênfase às formas utilizadas na construção de sólidos (paralelepípedos, cubos, tetraedros, cones, cilindros e esferas) e sua manipulação. O desenvolvimento da sequência para o $6^{\circ}$ ano A proporcionou o primeiro contato que os alunos, incluindo a Isabela, tiveram com figuras planas.

$\mathrm{Na}$ aplicação da atividade escolhida, não houve orientação diferente para a aluna analisada, mesmo ela sendo da educação especial. Foram formados grupos espontâneos de quatro alunos.

No primeiro momento, a intenção desta professora-pesquisadora era observar o desenvolvimento de conteúdos matemáticos, mas sabendo da dificuldade destes alunos em Língua Portuguesa, e como nessa atividade, a escrita era importante, foi possível observar também como eles estavam se expressando, oralmente ou por escrito.

Os alunos do $6^{0}$ ano sempre se envolveram muito nas aulas de matemática; eles todos gostavam de estudar os números e suas operações. A professora do 5o ano já havia comentado que tinham facilidade com números e pouca com a escrita. $O$ Caderno do Aluno (São Paulo, 2009) era novidade para eles, pois não são utilizados em escolas municipais de Campinas. Mesmo sem este contato, eles não sentiram dificuldades de entendimento, nesta atividade. A aluna Isabela participou das atividades como todos os outros. Inclui-se num grupo de quatro alunos, espontaneamente. 
Inicialmente, como previsto no Caderno do Aluno, foi feita a leitura do texto que explica como se trabalha em grupo. Assim que eles se organizaram, o que demorou um pouco, até que sentassem e se acalmassem, deu-se o inicio da atividade. Foi disponibilizado o material em folhas xerocadas para todos os alunos $\mathrm{e}$ no final era recolhida apenas uma por grupo. Nessas folhas havia um rol de figuras geométricas planas, as quais era preciso identificar e classificar, de acordo com o que se pedia em cada item.

No item 1 da atividade, cada aluno do grupo tinha que escolher uma das figuras geométricas planas e dar uma característica a ela. Em seguida, os outros alunos do grupo faziam o mesmo, tanto para a sua figura, quanto para aquela escolhida pelos colegas.

Neste item, a pergunta dos alunos que era mais frequente foi: Precisa ser uma característica diferente? No grupo onde Isabela estava não houve esta pergunta e todos os alunos citaram uma característica diferente, de imediato. Desse modo, verificamos que ela seguiu a atividade com toda normalidade, conforme as demandas da sequência didática. Sua única característica diferente era a escrita um pouco mais demorada que os demais, porém os colegas respeitavam isso.

No item 2, escolhia-se uma figura e se agrupavam todas as outras que tinham a mesma característica. Neste caso, no grupo de Isabela, houve um aluno que escolheu um triângulo e outro identificou uma figura não convexa de quatro lados como sendo também um triângulo, para o que ela imediatamente respondeu que não valia. Para tirar a dúvida, os colegas pediram a ajuda do professor.

Percebemos que ela estava inserida no grupo sem dificuldades e também sem diferenças. Os alunos aceitavam aquilo que ela propunha como resposta e deixam-na escrever, mesmo sendo mais lenta que eles nesta tarefa.

Depois de constatarem que suas respostas eram verdadeiras, os outros alunos, até mesmo de outros grupos, recorriam a ela em caso de dúvidas. Percebemos, neste momento, que Isabela tinha iniciativa e segurança no que estava falando.

O segundo momento da atividade previa que os alunos recorressem ao livro didático (Dante, 2011) e ao dicionário para procurar, quando tivessem dúvidas, os nomes das figuras e suas características formais. Neste momento, houve muita ajuda do professor. Porém, Isabela fez o que Ihe competia, não deixando para os outros 
colegas a execução de sua parte. Após a confecção de fichas individuais, os grupos as reuniram em uma única para ser entregue à professora.

Com relação aos conteúdos matemáticos propostos na atividade, verificamos que os alunos apresentaram bastante familiaridade com a nomenclatura das figuras geométricas planas, porém tiveram dificuldades na classificação de polígonos convexos ou não. Em geral, usavam a definição menos formal, chamando as figuras convexas de "sem buraco", mas não alcançaram a ideia geral de que, dados dois pontos quaisquer dentro da figura, o segmento que os liga fica totalmente contido aí. Isabela também mostrou essas mesmas dificuldades.

Outro problema foi com a identificação de quadriláteros generalizados: identificavam, de início, apenas quadrados, retângulos e paralelogramos. Porém quando a figura não se enquadrava nestas classificações, eles utilizavam figuras próximas conhecidas para nomeá-las. Por exemplo, a figura 1 abaixo, era chamada de "triângulo" e a figura 2 não era associada a nenhum nome. Somente após a orientação da professora para que contassem o número de lados dessas figuras é que um aluno arriscou o nome de "quadrilátero". Depois disso, os demais associaram ao nome que já tinham visto no estudo da geometria espacial.

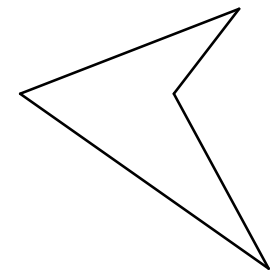

Figura 1: chamada de

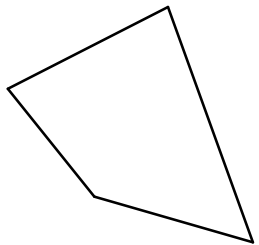

Figura 2: não classificada

Sobre a inter-relação da atividade com conhecimentos prévios, os alunos, em geral, usaram suas experiências cotidianas e escolares anteriores, para classificar os polígonos mais conhecidos (triângulos, retângulos, quadrados, paralelogramos, losangos e trapézios). Para a nomenclatura da circunferência, eles estavam menos familiarizados com o termo matemático e usaram o termo "bola". Este foi motivo para relacionarmos os conhecimentos estudados sobre sólidos geométricos, no caso, a esfera, e diferenciá-la da circunferência e do círculo, uma vez que eles não se recordaram dessas formalizações matemáticas.

Com relação à melhoria das habilidades de comunicação escrita, pudemos observar que houve ganhos na capacidade dos alunos de escreverem as ideias que 
queriam comunicar, porém ainda continuavam a cometer erros de ortografia e acentuação gráfica (por exemplo, a professora teve que escrever na lousa, a pedido dos alunos, as palavras "hexágono" e "heptágono"). 


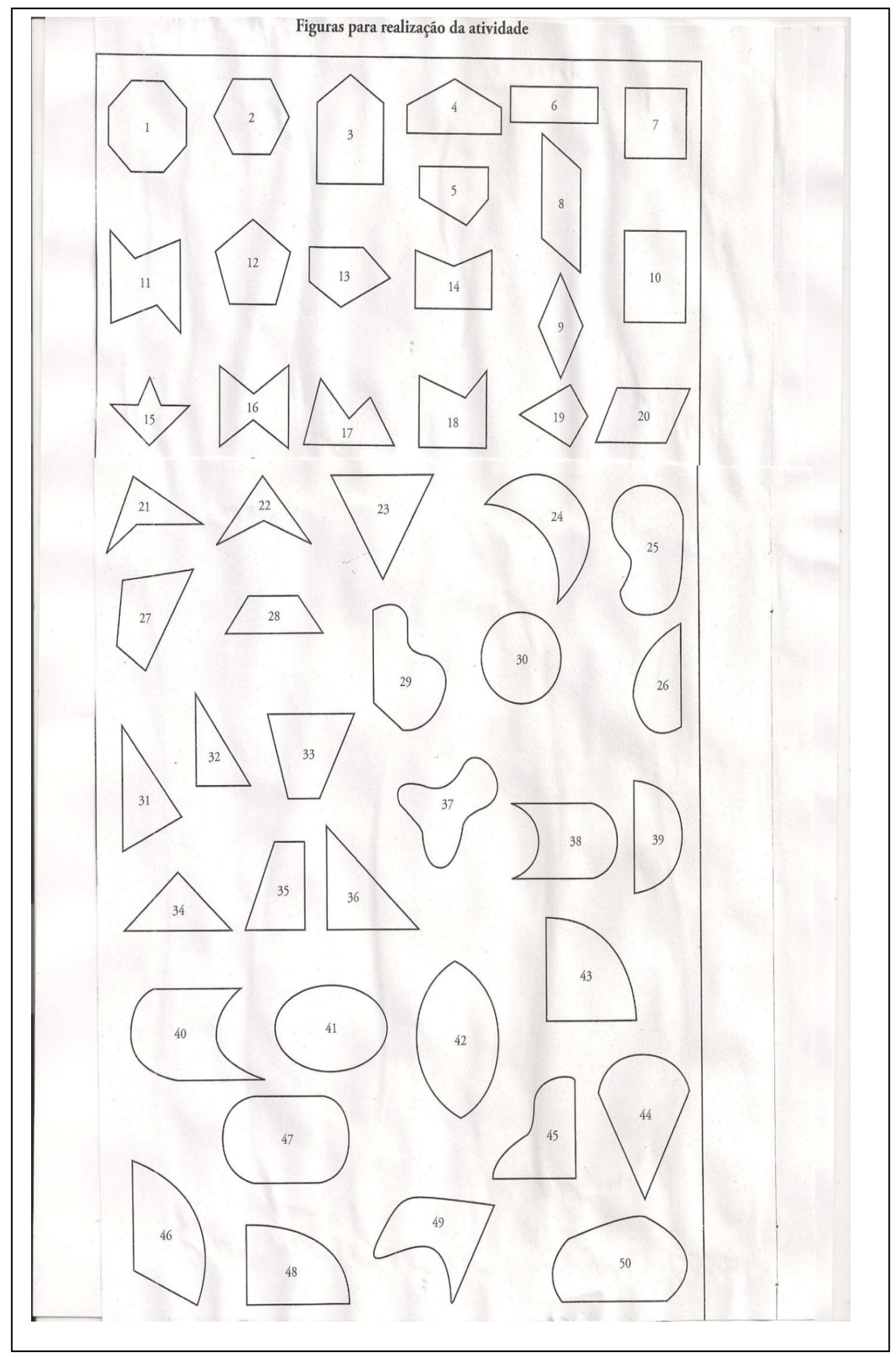

Rol de figuras utilizadas nas atividades ( São Paulo, 2009(a), p. 3, 4) 
1. Um participante do grupo deve escolher uma das 50 figuras e cada integrante deverá citar uma característica da figura escolhida. Em seguida, é a vez de outro participante escolher e repete-se a atividade até que todos os integrantes tenham escolhido, cada um, uma figura. Registre na tabela a seguir as características observadas.

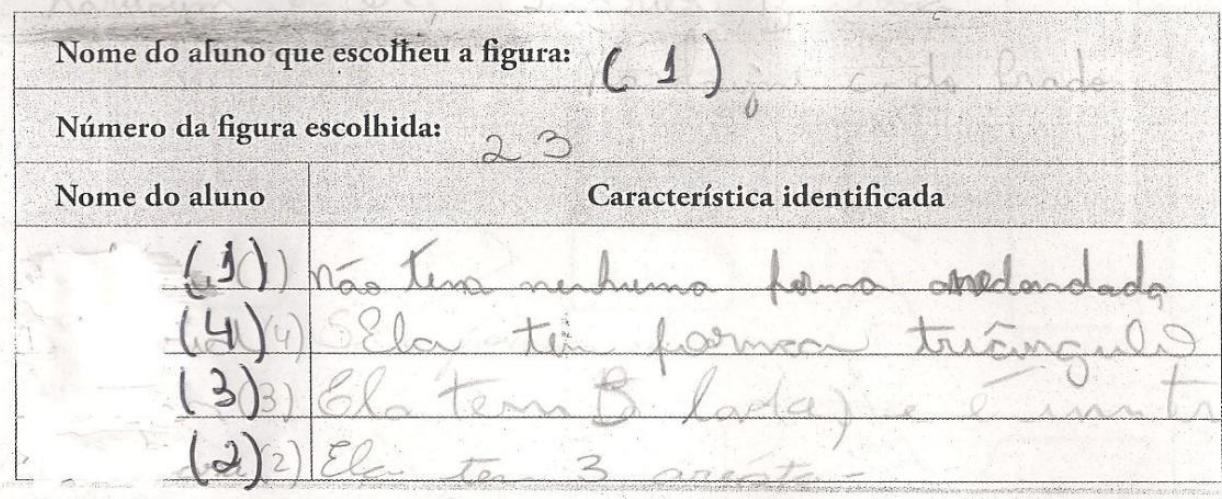

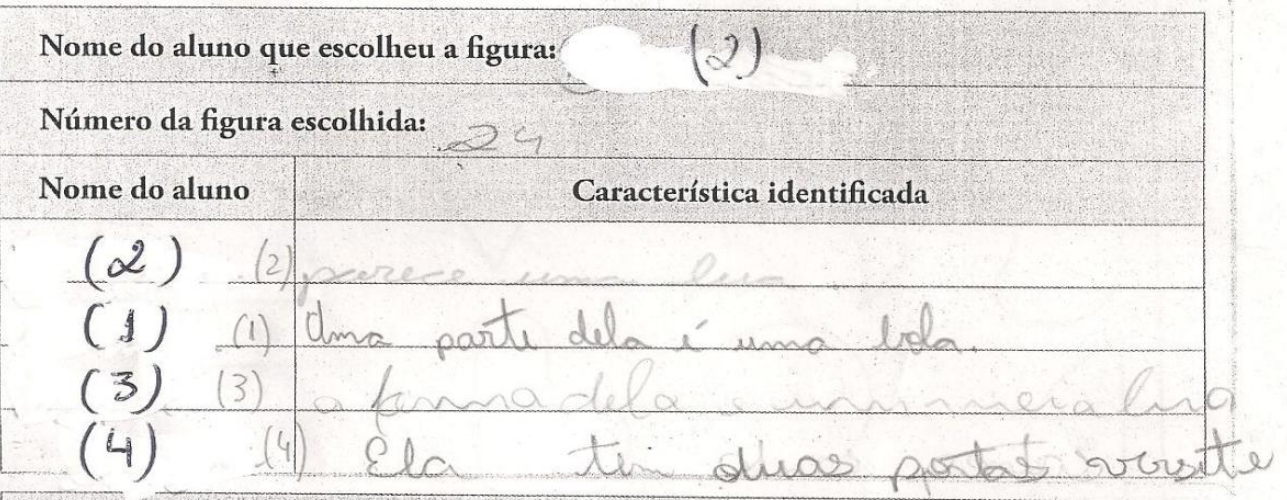

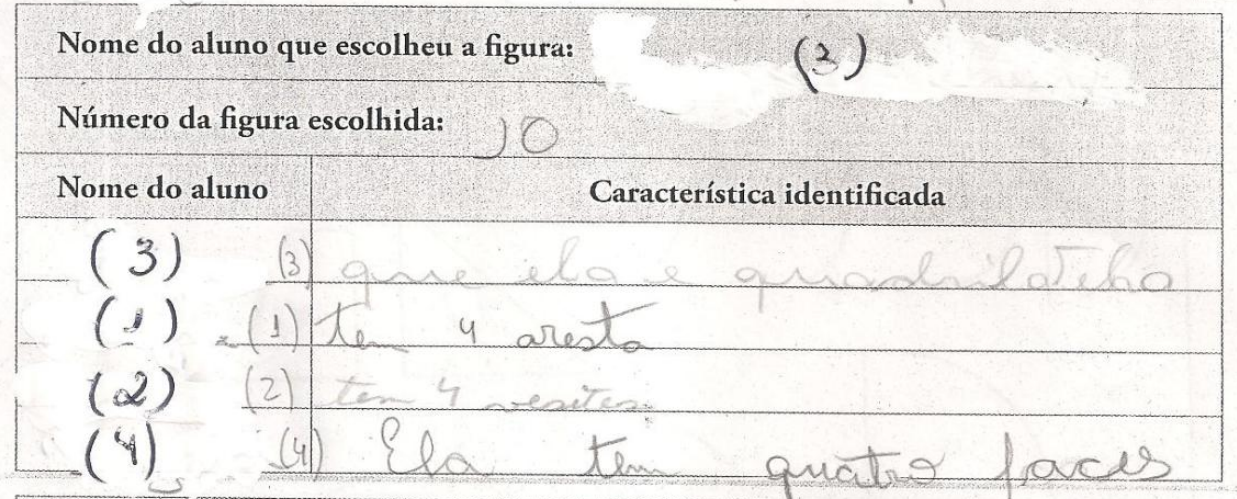

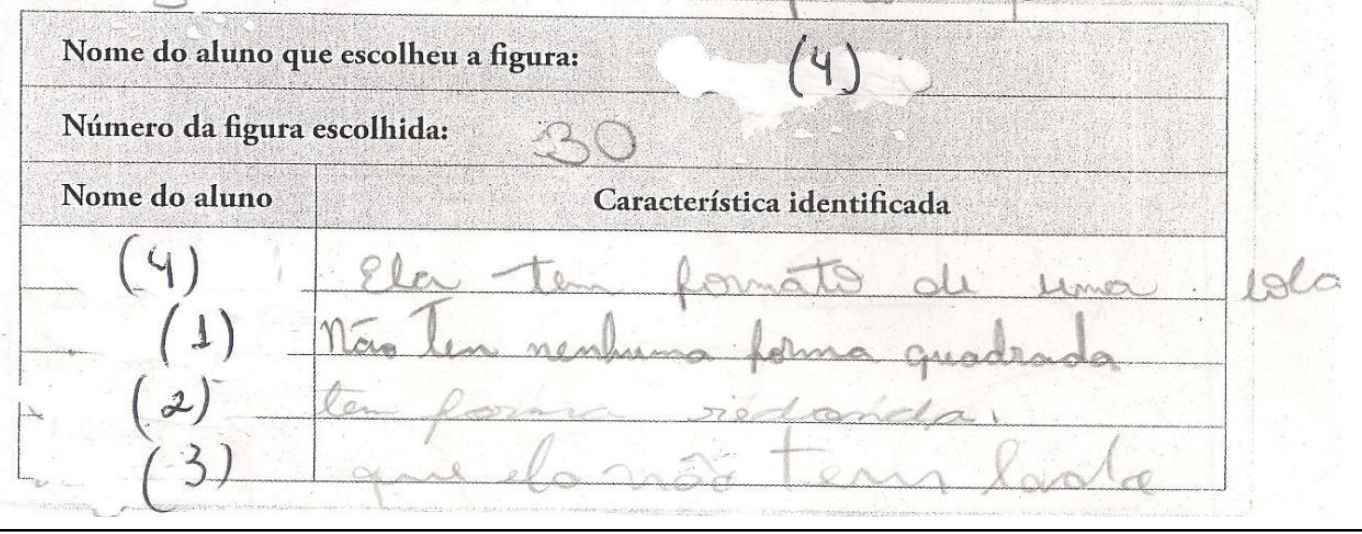

Atividade 1 (São Paulo, 2009(a) p.5) grupo 


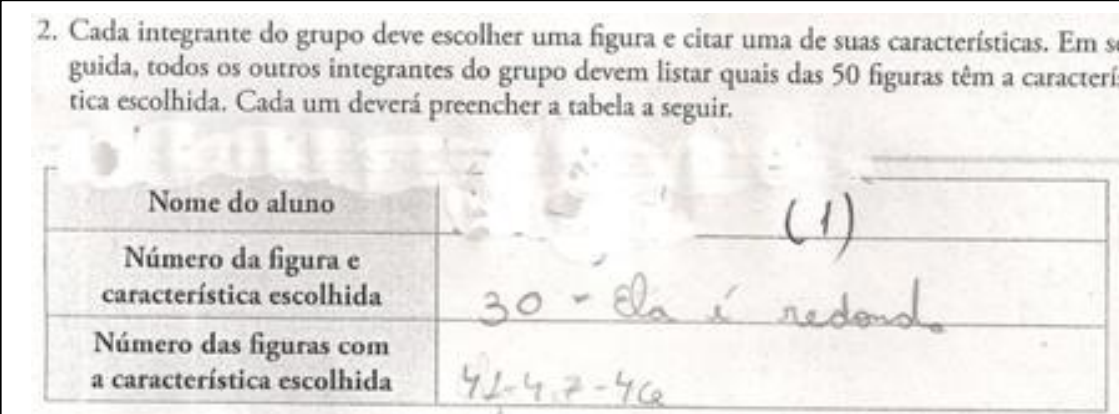
a característica escolhida

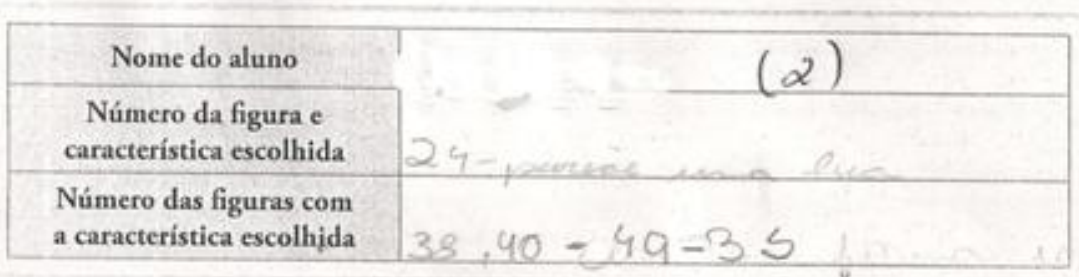

a característica escolhịda $38,40-49-35$

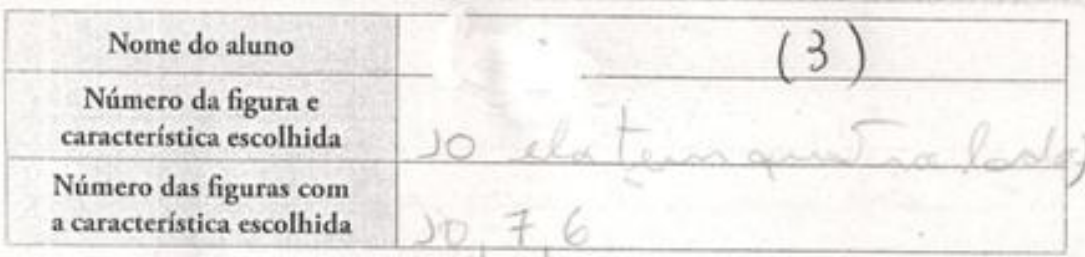
a característica escolhida

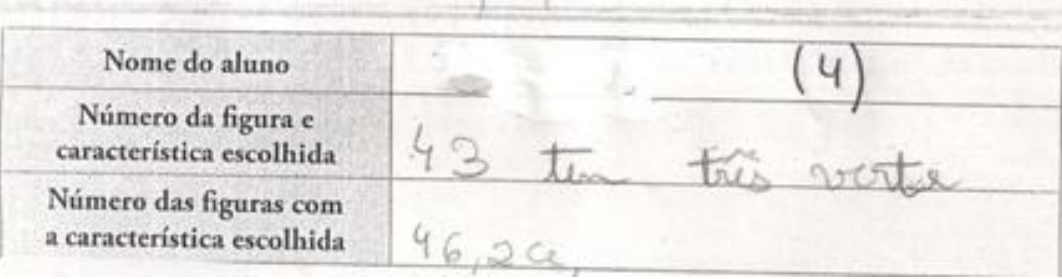

Atividade 2 feita pelo grupo da Isabela (São Paulo, 2009(a) p.6) 
Utilizando as 50 figuras com que você trabalhou em classe, preencha a tabela com os número das figuras que atendam às caracteristicas apresentadas.

\begin{tabular}{|c|c|}
\hline Caracteristica & Número das figuras \\
\hline $\begin{array}{l}\text { Figuras com apenas } 3 \text { lados } \\
\text { (retos ou curvos) }\end{array}$ & 44,43 \\
\hline Figuras com apenas 3 lados retos & $23,32,31,34$, \\
\hline Figuras com apenas 3 "bicos" & $23,36,34,32,31,43,49,46,45$ \\
\hline $\begin{array}{l}\text { Figuras com pelo menos } \\
4 \text { lados retos }\end{array}$ & $10,7,19,20,22,28,33,35,6,27$ \\
\hline $\begin{array}{l}\text { Figuras com pelo menos } 1 \text { par } \\
\text { de lados paralelos }\end{array}$ & Det \\
\hline $\begin{array}{l}\text { Figuras com todos os lados de } \\
\text { mesma medida }\end{array}$ & 23,3 \\
\hline $\begin{array}{l}\text { Figuras com lados formando } \\
\text { uma "quina" perfeita } \\
\text { (lados "em cruz") }\end{array}$ & $48,50,49,45,47,29,40,47,39,26$ \\
\hline
\end{tabular}

Atividade 3 feita pelo grupo de Isabela (São Paulo, 2009(a) p. 7) 
1. Muitas das características que você identificou na atividade em grupo (e na lição de casa) recebem nomes específicos na Matemática. Sua tarefa agora será estabelecer uma correspondência entre as nomenclaturas "oficiais" dessas características na Matemática e a descriçáo que você fez. Para a realizaçáo dessa tarefa, você poderá utilizar o dicionário e recorrer à ajuda de seu professor.

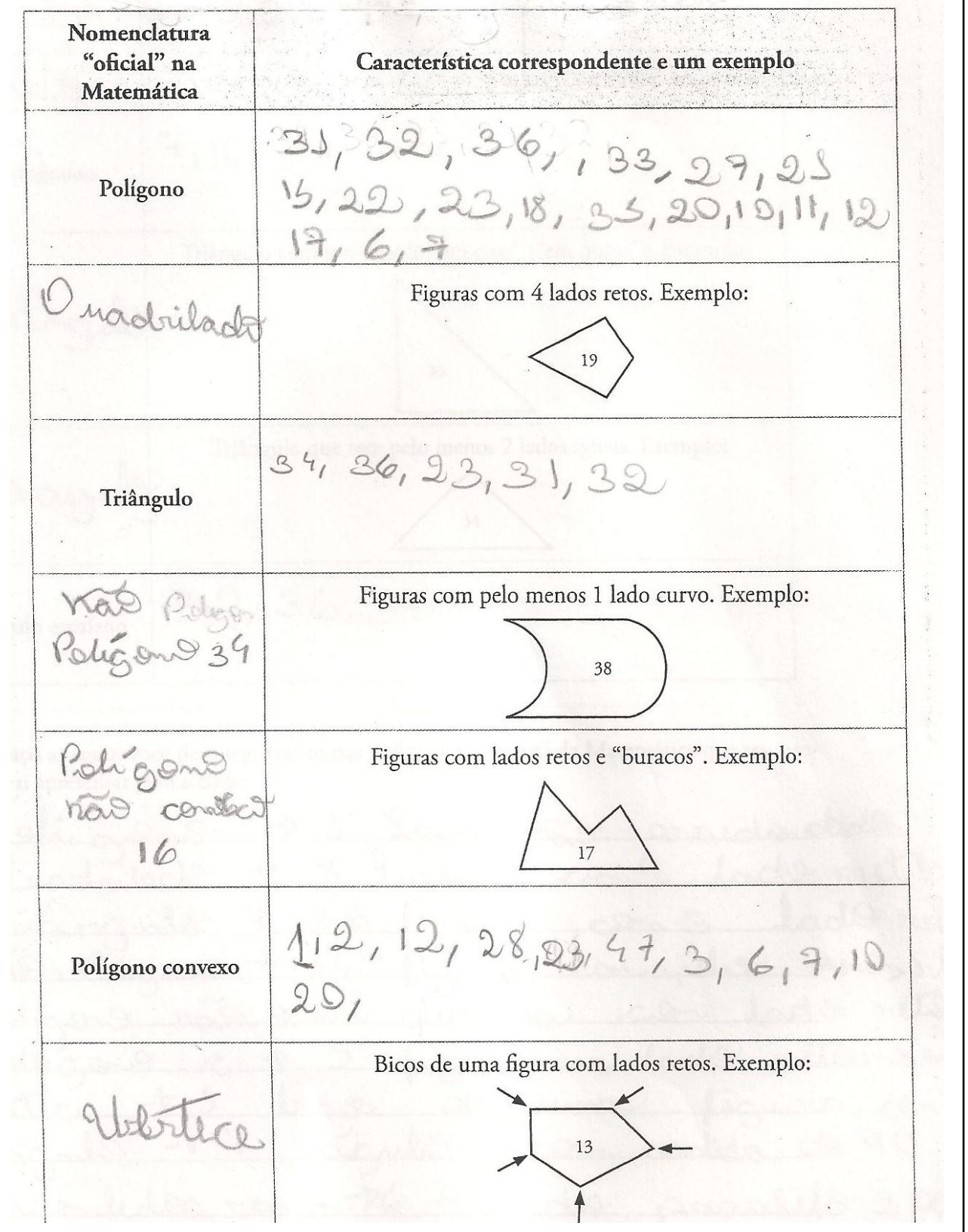

Atividade 3 feita pelo grupo da Isabela ( São Paulo(a), 2009 p.8) 


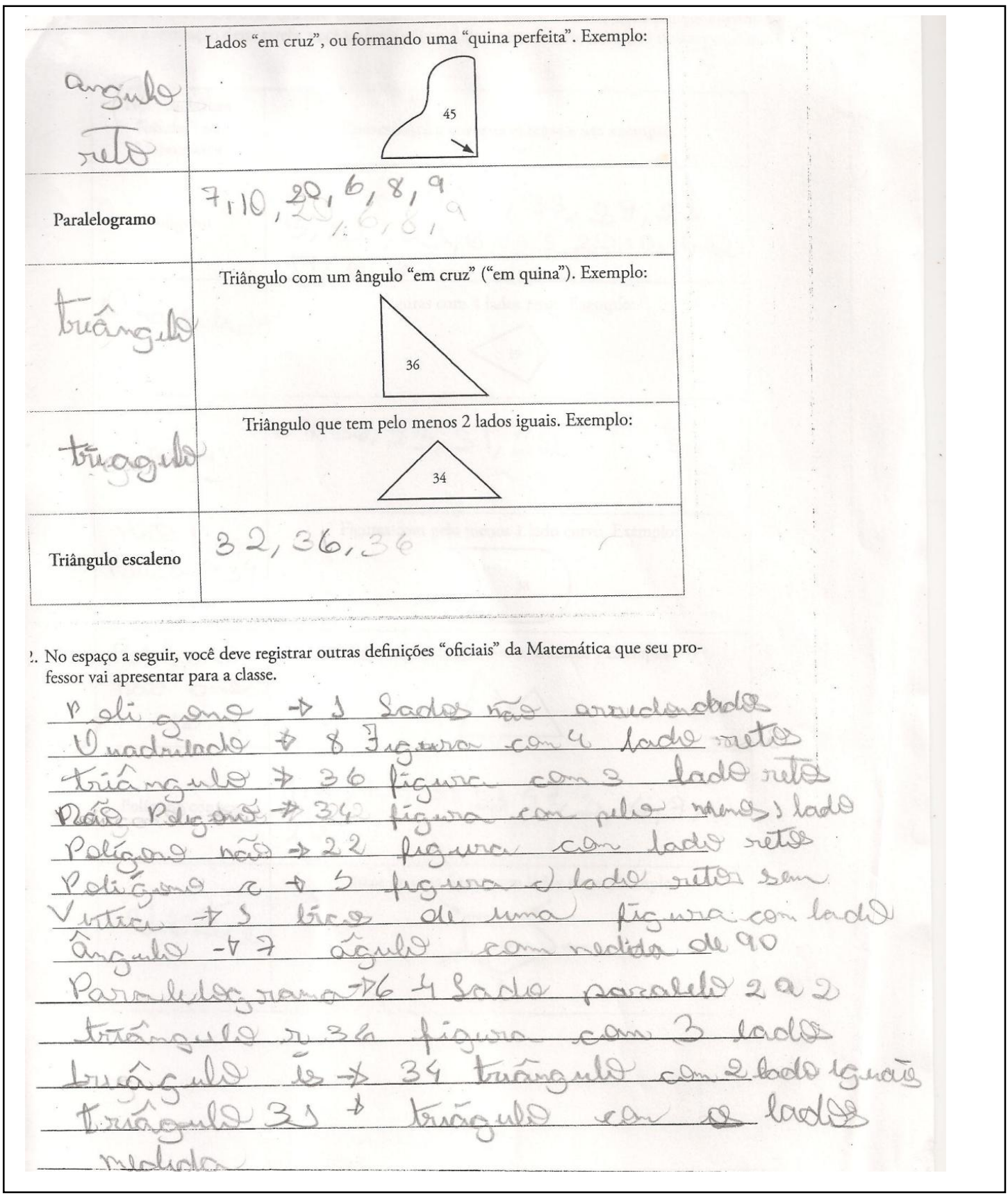

Continuação da atividade 3 (São Paulo, 2009(a) p. 9) 


\subsection{Atividade aplicada no 8ㅇ ano A:}

A atividade foi planejada e adaptada pensando na inclusão do aluno Miguel da educação especial, porém foi desenvolvida sem a sua presença. Pelo fato de sua deficiência precisar de ajuda de terceiros para sua locomoção, o aluno não estava presente na escola durante os últimos meses de aula e com isto a atividade não foi aplicada com ele (sua avó, que o acompanhava até à escola, estava doente).

A aula foi adiada e como este não compareceu por muito tempo, a atividade teve que ser aplicada sem a sua presença, Miguel não compareceu mais, até o final do ano letivo.

Este aluno tem dificuldade na fala, na locomoção, na comunicação em geral e seria este trabalho que desenvolveríamos com ele nas salas de aula, além da comunicação específica em matemática.

Como já observado, também para que os outros alunos tivessem um entendimento melhor da contextualização do Teorema de Tales, foi proposta pela professora-pesquisadora, uma atividade anterior àquela proposta no Caderno do Aluno (São Paulo- 2009), pois precisavam entender o enunciado do teorema. Primeiramente usamos as linhas do caderno de aula. O conceito sobre retas paralelas foi definido, logo que feito o desenho, pela professora. Percebemos que havia dificuldade em fazer as medidas com a régua: primeiro os alunos mediam partindo do um, e não do zero, (não tinham noção de distância). Outra dificuldade foi para escrever as unidades de medida não exatas (por exemplo: $5 \mathrm{~cm}$ e $4 \mathrm{~mm}$ ). Não houve problemas com os cálculos das razões entre os seguimentos estabelecidos, os quais foram feitos com calculadora.

Quando fomos à sala de informática, o software Geogebra não era conhecido dos alunos; então, na primeira aula, mostramos os comandos necessários para o desenvolvimento da atividade. Só depois de entendido como se traçavam retas quaisquer, paralelas, interseções de dois objetos e como se fazia para medir segmentos, é que fomos para a atividade proposta.

Ao entender como utilizar os comandos do Geogebra, os alunos perceberam que este facilitava o desenvolvimento da atividade, o que possibilitou que eles realmente vivenciassem esse outro recurso.

Quando fizeram as atividades no computador, a qual foi realizada em dupla, devido ao número de máquinas disponíveis, auxiliavam-se mutuamente, alguns 
tirando a dúvidas dos outros, em alguns momentos. Mesmo assim, de início, a ajuda da professora foi necessária a todas as duplas.

Depois de feita a atividade com o Geogebra, foi realizada a sequência com as atividades do Caderno do Aluno (São Paulo-2009(b)). Como nesta sequência as medidas já estavam indicadas, o que deveria ser feito foi facilmente compreendido pelos alunos e pudemos perceber que aquilo que fizemos usando um modelo matemático, poderia ser contextualizado em problemas que se aproximassem do cotidiano, já que alguns destes tratavam de construção de jardim, medidas de extensão de um lago e tamanho de ruas à volta de uma praça, como nas atividades que seguem.

\section{Atividade 1}

Sílvio é um jardineiro que está trabalhando no projeto de um canteiro triangular, em uma esquina da praça de seu bairro.

Inicialmente, ele propốe que o canteiro seja composto por dois tipos diferentes de folhagens rasteiras, e que a divisáo entre elas seja feita por uma faixa paralela à base $\mathrm{BC}$, indicada na figura pelo segmento $\mathrm{DE}$. Desse modo, Sílvio fez as seguintes mediçōes no canteiro: $\mathrm{AD}=4 \mathrm{~m}, \mathrm{DB}=4 \mathrm{~m}$ e $\mathrm{AE}=3 \mathrm{~m}$. Qual deve ser a medida de EC?
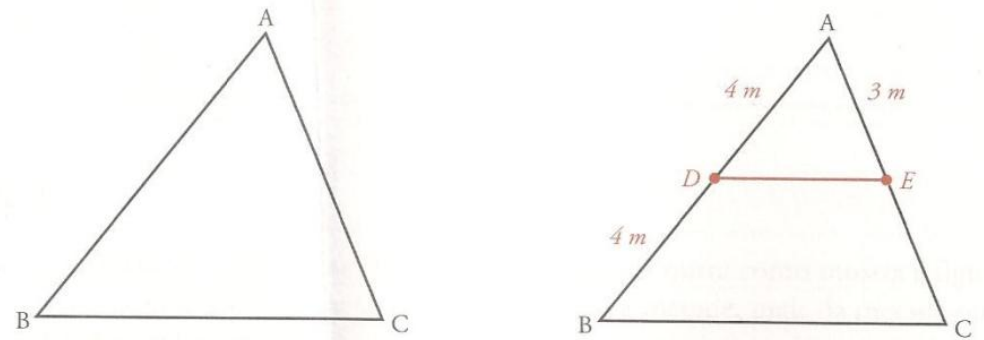

Atividade 1 - Caderno do Aluno (São Paulo, 2009(b), p. 14), $8^{\circ}$ ano vol 4. 


\section{Atividade 2}

Para fazer um ajuste em seu projeto, Sílvio posicionou o ponto $\mathrm{D}$ a $2 \mathrm{~m}$ do ponto $\mathrm{A}$, conforme indicado na figura a seguir. Encontre a nova medida de EC.

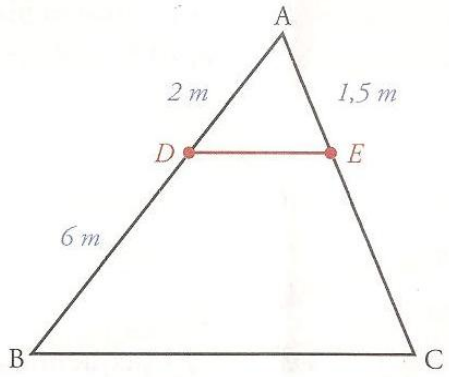

Atividade 2- Caderno do Aluno (São Paulo, 2009(b), p. 15), $8^{\circ}$ ano vol 4.

\section{Atividade 3}

A partir dos ajustes e dimensóes do projeto (Atividade 2), Sílvio percebeu que poderia explorar melhor o canteiro, dividindo-o mais uma vez por outra faixa paralela à base $\mathrm{BC}$, indicada na figura pelo segmento FG. Isso permitiria plantar outro tipo de folhagem, deixando o canteiro ainda mais bonito.

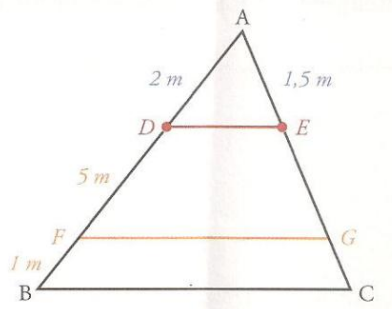

Com base nessas dimensôes, encontre as medidas de EG e GC e utilize o espaço a seguir para realizar os cálculos.

Atividade 3 - Caderno do Aluno (São Paulo, 2009(b), p.15), $8^{\circ}$ ano vol 4. 


\section{Atividade 4}

Lucas queria estimar a medida mais extensa do pequeno lago que havia perto de sua casa. Pensando sobre o problema, ele inicialmente fez um esquema da situaçáo, indicando essa extensáo por $\mathrm{AB}$ e imaginando dois triângulos $\mathrm{ABD}$ e $\mathrm{BCE}$, sendo as bases $\mathrm{AD}$ e EC paralelas (Figura 1). Depois, foi ao local e fincou 5 estacas, cada uma correspondente a um vértice dos triângulos de seu esquema. Contou com passos as medidas correspondentes aos lados $\mathrm{AE}, \mathrm{BD}$ e DC e completou seu esquema como na Figura 2.

Figura 1
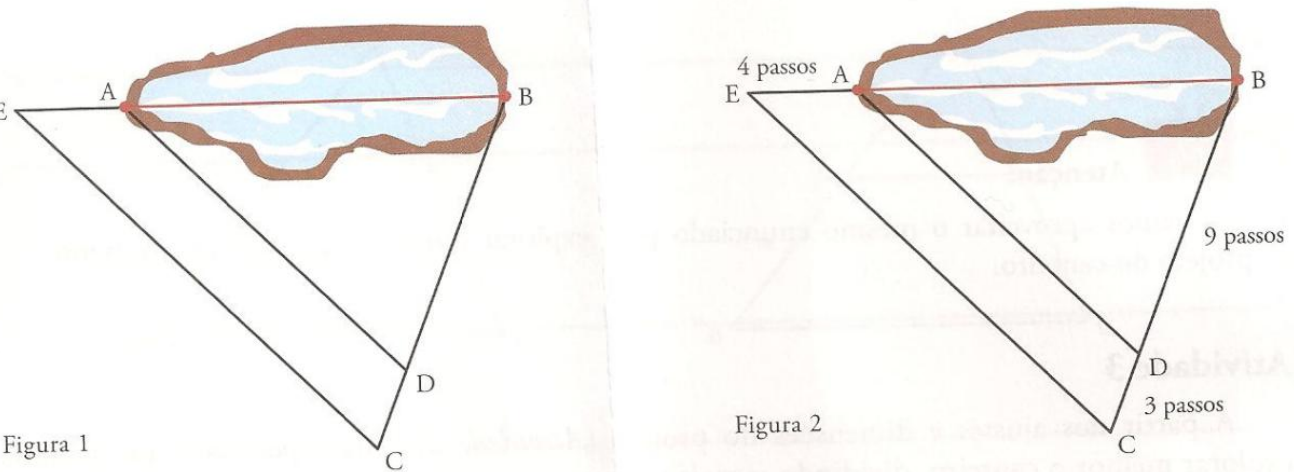

O procedimento criado por Lucas permite a resoluçáo do problema? Se sua resposta foi afirmativa, expresse os cálculos efetuados e o valor, em passos, encontrado por ele para a extensão $\mathrm{AB}$.

Atividade 4- Caderno do Aluno (São Paulo, 2009(b), p.16), $8^{\circ}$ ano vol 4. 


\section{Atividade 5}

De uma praça em formato retangular saem 4 avenidas, $\alpha, \beta, \varphi$ e $\theta$, uma de cada vértice do retângulo. Ligando cada par de avenidas, há três ruas, 1, 2 e 3, sempre paralelas em cada caso. Os pontos de encontro entre as ruas de mesmo número săo nomeados pelas letras do alfabeto, A, B, C, $\mathrm{D}$, etc. Observe na figura os pontos $\mathrm{M}$ e P. O ponto $\mathrm{M}$ está na rua "2 Leste", enquanto o ponto $\mathrm{P}$ está na rua "3 Norte".

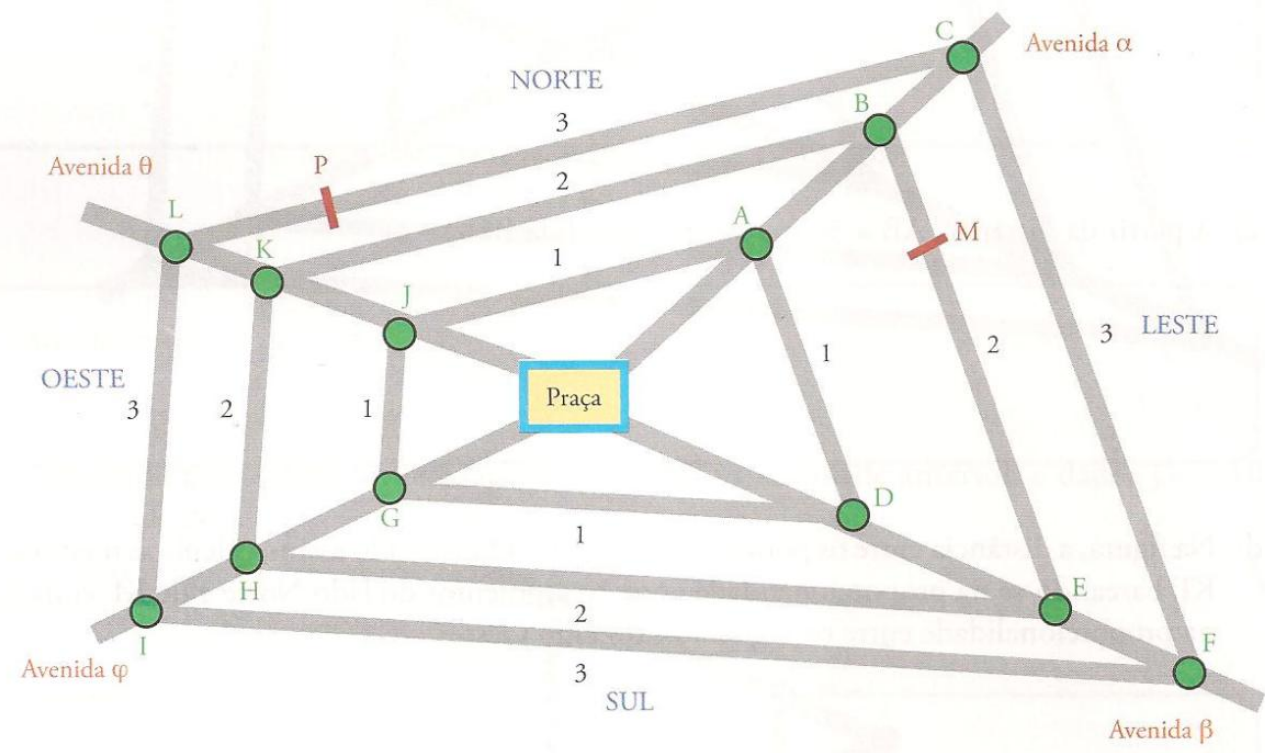

a) Considere apenas a parte Sul e as distâncias entre os pontos apresentadas a seguir, e verifique se é válida a proporção $\frac{\mathrm{GH}}{\mathrm{HI}}=\frac{\mathrm{DE}}{\mathrm{EF}}$.
$\mathrm{GH}=50 \mathrm{~m}$
$\mathrm{HI}=40 \mathrm{~m}$
$\mathrm{DE}=60 \mathrm{~m}$
$\mathrm{EF}=48 \mathrm{~m}$

Atividade 5- Caderno do Aluno, (São Paulo, 2009(b), p.17), $8^{\circ}$ ano vol 4.

b) A proporção verificada no item anterior é a expressão matemática do teorema de Tales, segundo o qual: se uma reta paralela a um lado de um triângulo intersecta os outros dois lados em pontos distintos, então ela determina segmentos que são proporcionais a esses lados. Considere agora o lado Leste da praça da figura e escreva a expressão matemática do teorema de Tales.

Atividade 5 b- Caderno do Aluno, (São Paulo, 2009(b), p.18), $8^{\circ}$ ano vol 4. 
c) A partir da distância $A B=36 \mathrm{~m}$, calcule a medida $B C$.

Atividade 5 c- Caderno do Aluno, (São Paulo, 2009(b), p.18), $8^{\circ}$ ano vol 4.

d) Na figura, a distância entre os pontos J e K é igual a $32 \mathrm{~m}$. Sendo assim, calcule as medidas de $\mathrm{KL}$ baseando-se na proporcionalidade entre os segmentos do lado Norte e de $\mathrm{KL}$ com base na proporcionalidade entre os segmentos do lado Oeste.

Atividade 5 d- Caderno do Aluno, (São Paulo, 2009(b), p.18), $8^{\circ}$ ano vol 4.

Durante as aulas na sala de informática, observamos que os alunos comentavam que, mesmo sendo difícil no começo, o uso do Geogebra facilitou a construção das retas e também as medidas dos segmentos, pois não precisaram usar a régua. Como estavam aprendendo a usar este software, pudemos explorar outros comandos, já que era uma novidade para eles. Em relação ao Teorema de Tales, houve uma comparação, feita por alguns alunos, quando realizaram a atividade5 do Caderno do Aluno (São Paulo, 2009,p.17-8ํㅜ ano vol.4), onde observaram que o desenho era parecido com aqueles feitos por eles na aula com 0 Geogebra.Com isso, acreditamos que o software foi importante para auxiliá-los a realmente compreender o Teorema em questão.

Esta atividade não foi registrada em vídeo, pois o aluno que deveria ser o objeto de estudo, como dito anteriormente, não estava presente.

Induzimos que talvez esta atividade com o Geogebra, e também o registro escrito dos conceitos envolvidos, seriam de muita dificuldade para Miguel, pois requerem muita habilidade de coordenação motora, mesmo com o mouse adaptado. Ficam, então, as perguntas: Será que observando a atividade ser realizada por outro colega da dupla de Miguel, o conteúdo seria assimilado por ele? Como ele faria o registro da atividade do Caderno do Aluno (São Paulo, 2009)? Teríamos que usar o computador para a escrita? A leitura, por ser de um texto considerado longo, para Miguel, deveria ser realizada e interpretada pelo professor?

Infelizmente, essas perguntas ainda não puderam ser respondidas, por causa da ausência de Miguel no desenvolvimento da atividade. Porém, com a aplicação 
para a classe regular, já pudemos constatar as dificuldades em geral e pudemos inferir outras adicionais que Miguel poderia apresentar. Fica também o registro e a reflexão sobre elas, para que, num futuro próximo, Miguel tenha contato com o software Geogebra, através desta e de outras atividades.

\section{Conclusão}

Durante os últimos meses de 2012, o meu olhar como professora pesquisadora foi para os alunos com necessidades educacionais especiais. Percebese que há diversos deles dentro da escola pública, e que muitos sequer são diagnosticados como tal, levando, nessas situações, ao fracasso em seu desenvolvimento e aprendizagem.

Os currículos das escolas municipais de Campinas e também das estaduais de São Paulo não têm indicativos de como proceder em relação a este alunado especial. Sabemos que existe uma legislação que os ampara em sua permanência na escola, mas e seu aprender? Como nestes documentos não há observações que nos levem a entender o trabalho com estas diferenças dentro de sala de aula, é importante que o professor busque fontes que o guiem nesta tarefa. Acreditamos que este trabalho se tornará uma destas fontes, fornecendo indícios de como outros docentes poderão utilizar os currículos oficiais e adaptá-los para atender também os alunos com necessidades educacionais especiais.

Ao adaptar a atividade do aluno do 8a ano, utilizamos o software Geogebra. Será que este facilitaria o aprendizado do aluno Miguel? Esta era a pergunta inicial, porém constatamos que ele fez melhorar o interesse e empenho de todos na sala. Sendo assim, podemos considerar que esta atividade, que em um primeiro momento foi adaptada ao aluno com necessidades educacionais especiais, promoveu uma verdadeira integração, onde todos se beneficiaram.

Para os alunos que estavam aprendendo sobre proporcionalidade, a exploração do Teorema de Tales, através de régua, complementarmente, com o uso do software Geogebra, expressou a importante combinação de elementos geométricos e numéricos, permitindo desenvolver diversas noções matemáticas, como o estudo da semelhança de figuras. Os alunos verificaram suas várias aplicações nas atividades contextualizadas; muitos relacionaram o conhecimento 
matemático com o uso do Geogebra e as situações-problema apresentadas nas atividades do Caderno do Aluno (São Paulo, 2009).

Com relação à questão da inclusão de pessoas com necessidades especiais, e principalmente aquelas portadoras de deficiência (no sentido técnico do termo), em escolas comuns, vimos que os alunos podem ter o mesmo diagnóstico, mas não devemos tratá-los com igualdade na construção do conhecimento, no momento de planejar as ações pedagógicas. A aluna Isabela, que teve ao nascer paralisia cerebral, embora em situação parecida com o aluno Miguel, não precisou de adaptação para a atividade de geometria escolhida para a sua turma: sua deficiência física permitiu utilizar os instrumentos regulares da sala de aula e escrever com precisão. Partindo desta observação, podemos concluir que os planos de ensino, para a educação especial, devem partir de um princípio de igualdade, no sentido de que todos têm direito a aprender, mas nosso estudo indica que estes planos devem ser adaptados e adequados a este aluno específico, sem, entretanto, isolá-los da integração com os demais em sala de aula.

Entretanto, ainda a verificamos, em muitas escolas, segundo relatos informais de colegas, particularmente naquelas que não têm sala de recurso e onde não há um professor da educação especial que acompanhe e ajude no diagnóstico de deficientes, que este alunado é tirado de perto dos amigos e de sua casa, enfrentando transporte (quando existe) para chegar até a escola, porém muitas vezes, não se integra verdadeiramente a ela, ou fica isolado dentro da sala de aula comum, sem envolver-se nas atividades didáticas. Isso pode gerar a desistência da família para a promoção de seu desenvolvimento e aprendizagem nessas escolas e pode levá-la a considerar apenas a participação do estudante em outras especiais, privando-o de um convívio social mais amplo.

Nós, professores, precisamos de mais orientações para termos confiança ao elaborar planos de ensino. Já fazemos adaptações, em alguns casos, porém alunos como o Miguel, que precisam de recursos diversos para seu aprendizado, não são frequentes nas aulas, e ainda, há a necessidade de conhecermos os materiais alternativos que poderíamos utilizar, as tecnologias assistivas ('notebook' e 'mouse' adaptado), assim como os métodos de ensino adequados. Precisamos, então, de formação continuada, principalmente professores do ensino fundamental, pois este aluno tem o direito de frequentar uma escola regular e nela estar verdadeiramente integrado. 
Procurar métodos e formas diferenciadas de aprendizagem é uma rotina para quem trabalha com educação, e principalmente coma matemática. Assim, não podemos ter planos engessados, com atividades em sequencias pré-estabelecidas, antes de conhecer a realidade dos alunos, pois as diferenças que encontramos em salas de aula, muitas vezes, requerem adaptações de conteúdos e materiais para atingir todos os envolvidos.

Nos casos aqui estudados, pudemos constatar que a aluna Isabela teve, no início de sua vida escolar, professores que identificaram suas deficiências e assim conseguiram adaptá-la à escola comum, e hoje, no $7^{\circ}$ ano, podemos perceber que, mesmo com suas limitações físicas, ela participa de todas as atividades, inclusive das aulas de educação física. Já o aluno Miguel também tem acompanhamento na escola e nas instituições desde muito pequeno, o que nos auxiliou a saber como nos comunicar com ele, assim como no diagnóstico de suas limitações. Como ele usa cadeira de rodas, há a necessidade de ajuda para a sua locomoção, porém podemos sempre contar com o apoio dos outros alunos para isto. Desse modo, temos tido alguns apoios para promover a inclusão, porém, no que diz respeito às atividades didáticas, é o professor que deve buscar os meios de adaptar-se e integrar-se às necessidades dos alunos especiais.

Então, voltando às perguntas que tínhamos anteriormente: $O$ aluno da educação especial, seja qual for a sua deficiência, acompanha as atividades dadas em sala de aula de uma escola pública comum? As atividades propostas no Caderno do Aluno são suficientes para atingir a aprendizagem desejada? Em todos os casos de inclusão de alunos com deficiência, as aprendizagens desejadas e alcançadas serão as mesmas?

Percebemos, como resultado desta pesquisa, que o aluno com necessidades especiais irá acompanhar as atividades da sala de aula comum, desde que estas sejam adaptadas para ele, e isto deve ser feito caso a caso, para tentar atingir a aprendizagem desejada. Com isto, verificamos que só as atividades do Caderno do Aluno talvez não sejam suficientes, pois o aluno Miguel tem limitações de escrita e de coordenação motora, e que as adaptações pensadas para ele, através do software Geogebra, foram também importantes para gerar mais significados para os demais.

Concluímos, então, que os alunos deficientes, assim como todos os outros, devem estar incluídos no sistema educacional de uma escola comum (ou regular) e que esta inclusão deve ocorrer com respeito às suas diferenças e referir-se a todos, 
até mesmo àqueles com outros tipos de necessidades especiais (por exemplo, com atrasos momentâneos que podem ser corrigidos), oferecendo condições de aprendizagem sem discriminações, e sem espaços separados entre eles. 


\section{Referências}

ANDRÉ, M.E.D.A. Etnografia da Prática Escolar. Campinas, SP: Papirus, 1995.

CAMPINAS (Município de). Secretaria Municipal de Educação. Diretrizes Curriculares da Educação Básica para o Ensino Fundamental e Educação de Jovens e Adultos Anos Finais: Um Processo Contínuo de Reflexão e Ação. Campinas- SP, 2010.

COLL, C., MARCHESI, A., PALACIOS, J. Desenvolvimento psicológico e educação - Transtornos de desenvolvimento e necessidades educativas especiais. Porto Alegre, RS: Artmed, 2004.

DANTE, L.R., Tudo é matemática, 3a.ed. São Paulo: Ática, 2011.

MANTOAN, M.T., PRIETO, R.G., Inclusão escolar: pontos e contrapontos. São Paulo, SP: Summus, 2006.

MANTOAN, M.T., BATISTA, C. A. M., Atendimento Educacional especializado (Deficiência Mental) - Formação continuada à distância para o atendimento educacional especializado. Brasília-DF: SEESP/SEED/MEC, 2007. Disponível em: http://portal.mec.gov.br. Acesso em 08 de janeiro de 2013.

PONTE, J. P. Estudos de caso em educação matemática. Bolema, 25, 105-132. 2006, disponível em: <http://www.educ.fc.ul.pt>. Acesso em 08 janeiro de 2013.

SÃO PAULO (Estado de). Secretaria da Educação. Caderno do Aluno. Matemática - 6a ano. São Paulo: IMESP, v. 4, 2009(a).

SÃO PAULO (Estado de). Secretaria da Educação. Caderno do Aluno. Matemática - 8o ano. São Paulo: IMESP, v. 3, 2009(b).

SÃO PAULO (Estado de). Secretaria da Educação. Caderno do Professor. Matemática, ensino fundamental - 6o ano/5a série. São Paulo: IMESP, v. 4, 2009(c). 
SÃO PAULO (Estado de). Secretaria da Educação. Caderno do Professor. Matemática, ensino fundamental - $8^{\circ}$ ano/7a série São Paulo: IMESP, v. 3, 2009(d).

SÃO PAULO (Estado de). Secretaria estadual da Educação. Currículo do Estado de São Paulo - Matemática e suas tecnologias. 1ํe ed.rev. 2012.

UNESCO. Declaração de Salamanca, p.11,12, 2004. Disponível em: $<$ http://redeinclusao.web.ua.pt> Acesso em: 24 de fevereiro de 2013.

ZUFFI, E.M., JACOMELLI, C.V. e PALOMBO, R. D. Pesquisas sobre a inclusão de alunos com necessidades especiais no Brasil e a aprendizagem em Matemática. Anais da XIII CIAEM- Conferência Interamericana de Educação Matemática, Recife, PE, 26 a 30 de junho de 2011, 12 p. 